\title{
Preclinical and Clinical Antioxidant Effects of Natural Compounds against Oxidative Stress-Induced Epigenetic Instability in Tumor Cells
}

\author{
Abdelhakim Bouyahya ${ }^{1}{ }^{(0}$, Naoual El Menyiy ${ }^{2}{ }^{(}$, Loubna Oumeslakht ${ }^{3}$, Aicha El Allam ${ }^{1}$, Abdelaali Balahbib ${ }^{4}\left({ }^{\circ}\right.$, \\ Abdur Rauf ${ }^{5}\left(\right.$ D) , Naveed Muhammad ${ }^{6}$, Elena Kuznetsova ${ }^{7}$, Marina Derkho ${ }^{8}$, Muthu Thiruvengadam ${ }^{9, *}$ (i), \\ Mohammad Ali Shariati ${ }^{10}$ (1) and Nasreddine El Omari ${ }^{11}$
}

Citation: Bouyahya, A.; El Menyiy, N.; Oumeslakht, L.; El Allam, A.; Balahbib, A.; Rauf, A.; Muhammad, N.; Kuznetsova, E.; Derkho, M.; Thiruvengadam, M.; et al. Preclinical and Clinical Antioxidant Effects of Natural Compounds against Oxidative Stress-Induced Epigenetic Instability in Tumor Cells. Antioxidants 2021, 10, 1553. https:// doi.org/10.3390/antiox10101553

Academic Editor: Stanley Omaye

Received: 24 August 2021

Accepted: 22 September 2021

Published: 29 September 2021

Publisher's Note: MDPI stays neutral with regard to jurisdictional claims in published maps and institutional affiliations.

Copyright: (c) 2021 by the authors. Licensee MDPI, Basel, Switzerland. This article is an open access article distributed under the terms and conditions of the Creative Commons Attribution (CC BY) license (https:// creativecommons.org/licenses/by/ $4.0 /)$.
1 Laboratory of Human Pathologies Biology, Department of Biology, Faculty of Sciences, and Genomic Center of Human Pathologies, Faculty of Medicine and Pharmacy, Mohammed V University in Rabat, 4 Avenue Ibn Batouta, Rabat P.O. Box 1014, Morocco; boyahyaa-90@hotmail.fr (A.B.); elallamaicha@gmail.com (A.E.A.)

2 Department of Biology, Faculty of Science, University Sidi Mohamed Ben Abdellah, P.O. Box 1796 Fez 30 000, Morocco; Nawal.ELMENYIY@usmba.ac.ma

3 Institute of Biological Sciences (ISSB-P), Mohammed VI Polytechnic University (UM6P), Benguerir 43150, Morocco; loubnaoumeslakht@gmail.com

4 Laboratory of Biodiversity, Ecology and Genome, Faculty of Sciences, Mohammed V University, Rabat 4 Avenue Ibn Batouta, Rabat P.O. Box 1014, Morocco; balahbib.abdo@gmail.com

5 Department of Chemistry, University of Swabi, Anbar, Khyber Pakhtunkhwa, Swabi 23430, Pakistan; mashaljcs@yahoo.com

6 Department of Pharmacy, Abdul Wali Khan University Mardan, Khyber Pakhtunkhwa, Mardan 23200, Pakistan; drnaveedrph@gmail.com

7 Department of Industrial Chemistry and Biotechnology, Orel State University named after I.S. Turgenev, 95 Komsomolskaya St., 302026 Orel, Russia; elkuznetcova@ya.ru

8 Institute of Veterinary Medicine, South-Urals State Agrarian University, 13 Gagarin St., Chelyabinsk Region, 457100 Troitsk, Russia; derkho2010@ya.ru

9 Department of Crop Science, College of Sanghuh Life Science, Konkuk University, Seoul 05029, Korea

10 Department of Scientific Research, K.G. Razumovsky Moscow State University of Technologies and Management (The First Cossack University), 73, Zemlyanoy Val St., 109004 Moscow, Russia; shariatymohammadali@gmail.com

11 Laboratory of Histology, Embryology and Cytogenetic, Faculty of Medicine and Pharmacy, Mohammed V University in Rabat, 19 Rue Tarik Ibnou Ziad, Rabat P.O. Box 9154, Morocco; nasrelomari@gmail.com

* Correspondence: muthu@konkuk.ac.kr; Tel.: +82-24500577

\begin{abstract}
ROS (reactive oxygen species) are produced via the noncomplete reduction in molecular oxygen in the mitochondria of higher organisms. The produced ROS are placed in various cell compartments, such as the mitochondria, cytoplasm, and endoplasmic reticulum. In general, there is an equilibrium between the synthesis of ROS and their reduction by the natural antioxidant defense system, called the redox system. Therefore, when this balance is upset, the excess ROS production can affect different macromolecules, such as proteins, lipids, nucleic acids, and sugars, which can lead to an electronic imbalance than oxidation of these macromolecules. Recently, it has also been shown that ROS produced at the cellular level can affect different signaling pathways that participate in the stimulation of transcription factors linked to cell proliferation and, consequently, to the carcinogenesis process. Indeed, ROS can activate the pathway of tyrosine kinase, MAP kinase, IKK, NF-KB, phosphoinositol 3 phosphate, and hypoxia-inducible factor (HIF). The activation of these signaling pathways directly contributes to the accelerated proliferation process and, as a result, the appearance of cancer. In addition, the use of antioxidants, especially natural ones, is now a major issue in the approach to cancer prevention. Some natural molecules, especially phytochemicals isolated from medicinal plants, have now shown interesting preclinical and clinical results.
\end{abstract}

Keywords: oxidative stress; cancer; epigenetic; bioactive compounds 


\section{Introduction}

Oxygen molecules are central molecules that live in cells and are responsible for the oxidation of organic matter. This molecule is considered as a final electron acceptor during cellular respiration in higher organisms of eukaryotic cells. The final oxidation reaction takes place between the protons generated during the oxidation of organic matter and the molecular oxygen located at the mitochondrial level. This reaction results in the formation of $\mathrm{H}_{2} \mathrm{O}$ as the final product of cellular respiration; however, intermediate reactions can occur during this oxygen reduction, and they can give certain reactive oxygen molecules, for example, hypochlorous acid (HOCL), singlet oxygen $\left({ }^{1} \mathrm{O}_{2}\right)$, hydrogen peroxide $\left(\mathrm{H}_{2} \mathrm{O}_{2}\right)$, and lipid peroxide $(\mathrm{LOOH})$, hydroxyl radical (-OH), alkoxy radical (RO-), superoxide anion $\left(\mathrm{O}_{2}-\right)$, and hydroperoxyl radical $\left(\mathrm{HO}_{2}-\right)$ [1]. In the homeostasis equilibrium, the production of ROS is controlled by a natural antioxidant system constituting some endogenous enzymes that have the capacity to eliminate or reduce these free radicals. These enzymes include catalase (CAT), glutathione peroxidase (GPx), glutathione reductase (GR), and superoxide dismutase (SOD). An imbalance in the respiratory chain and an excessive production of ROS with a low antioxidant capacity have a detrimental impact on many macromolecules. In fact, ROS can oxidize certain macromolecules, such as proteins and nucleic acids. They can also peroxidize lipids, which leads to oxidation and, therefore, an electronic imbalance of these vital molecules [1].

The ROS generated during this reduction in molecular oxygen are involved in several pathologies via many mechanisms: directly, by their involvement in instability in macromolecules in particular oxidation and, consequently, mutation of nucleic acids (DNA), and, indirectly, because ROS can also induce intracellular signaling via which they can activate certain phosphorylation pathways and deactivate others. Indeed, the production of ROS has been rubbished as an indicator of cell proliferation, as most of these reactive species have a positive action on the signaling pathways that stimulate cell proliferation and a negative action on the proteins that control cell division. Via these mechanisms, ROS can induce deregulation of gene expression, since they can change gene expression via a disruption of essentially epigenetic pathways (stimulating transcription factors responsible for cell proliferation and inhibiting others responsible for cell cycle control). This epigenetic instability essentially translates into the ectopic expression of oncogenes and antioncogenes, which favors the process of cancerization. This epigenetic instability can, with time, in one way or another, generate a genetic instability via the induction of the mutation, including those affecting oncogenes (dominant mutation, advantageous) and antioncogenes mutation (deleterious mutation, disadvantageous). In addition, nowadays it appears that the treatment of some cancers must pass through the inhibition of the oxidative process and the process of epigenetic deregulation [2]. Antioxidants that can prevent the production of ROS or possibly block the action of these reactive oxygen species are a major therapeutic way to reinforce the anticancer treatments that exist today.

The use of antioxidants to treat diseases is ancient history in medicine; many antioxidants today are used for the medication of various diseases, in particular, inflammatory diseases (use of vitamin C). For the treatment of cancer, the use of targeted antioxidants (antioxidants that specifically target the production or action of ROS) cannot give direct results for the reason that the pathways of action of ROS are diverse and their mechanisms of action are poorly explained; in this sense, the use of natural antioxidants (via food) could play a very significant role in the prevention of diseases related to the braid, in particular, cancer. Indeed, currently, many preclinical and clinical investigations have shown that some natural substances, in particular, those present in medicinal food plants, have very remarkable antioxidant properties [3].

Therefore, the use of these medicinal food plants could play an important role in implementing natural antioxidants to prevent the appearance of various cancers, but also to use them as a therapeutic agent combined with conventional chemotherapy. The aim of our work is to explain molecularly of the relationship between the production of ROS at the cellular level and the defense system that controls this production, as well as to 
demonstrate how ROS are directly or indirectly involved in the process of carcinogenesis, and, finally, to propose bioactive molecules from traditional medicine. As an antioxidant agent for the prevention and therapy of several highly oxidation-related cancers.

\section{Oxidative Stress Signaling Pathways}

\section{1. $R O S$}

Oxygen is a vital gas that is crucial for the production of energy in aerobic organisms, since it is the terminal acceptor of electrons during respiration. It has one unpaired electron in each of its two spins and it is considered as a free di-radical that has low reactivity. Additional energy from external (e.g., ionizing irradiations) or internal sources (e.g., electron transport chains) converts oxygen to a more reactive state, inducing the transfer of its electron between donors and acceptors through redox reactions, which generate ROS. ROS include nonradical molecules, such as $\mathrm{HOCL},{ }^{1} \mathrm{O}_{2}, \mathrm{H}_{2} \mathrm{O}_{2}$, and $\mathrm{LOOH}$, and free radicals that have one or more unpaired electrons, such as $\mathrm{O}_{2}{ }^{\bullet}$, , $\mathrm{RO}{ }^{\bullet}, \mathrm{OH}, \mathrm{HO}_{2}{ }^{\bullet}$, etc. [1].

ROS can be generated from exogenous and endogenous sources. Endogenous sources include the immune system, ischemia, infection, cancer, psychological stress, aging, etc. [4] Exogenous sources include ionizing radiations, nonionizing radiations (e.g., ultraviolet A, B, or C) [5], pollutants, drugs, xenobiotics (e.g., pesticides, toxins, and herbicides), chemicals (e.g., heavy metals, chemotherapy, and alcohol), and food [6].

ROS are delivered in several cellular compartments, including the plasma membrane, peroxisomes, endoplasmic reticulum, and mitochondria. Their formation is mediated by different enzymatic systems, including nicotinamide adenine dinucleotide phosphate (NADPH) oxidase (NOX) [7], cytochrome $\mathrm{C}$ oxidase (CCO) of the mitochondrial electron transport chain [8], lipoxygenase [9], xanthine oxidase [10], cyclooxygenase, cytochrome P450 [11], monooxygenase, and nitric oxide synthase [12].

Adding an electron to an oxygen spin results in the production of $\mathrm{O}_{2}{ }^{\bullet-}$ with a single unpaired electron and a negative charge. This reaction can be mediated by different enzymes, such as the NADPH oxidase family that comprises seven enzymes, including Nox1-5 and Duox1-2. These enzymes transfer electrons across membranes onto oxygen to generate $\mathrm{O}_{2}{ }^{\bullet-}$ [13]. $\mathrm{O}_{2}{ }^{\bullet-}$ can further be reduced to $\mathrm{H}_{2} \mathrm{O}_{2}$ by spontaneous dismutation or by SOD, which are essential enzymes required for the control and prevention of the formation of high levels of $\mathrm{ROS}$ [14]. $\mathrm{O}_{2}{ }^{\bullet-}$ may also interact with peroxynitrite $\left(\mathrm{ONOO}^{-}\right)$ and nitric oxide $\left(\mathrm{NO}^{\bullet}\right)$. Oxidation of l-arginine to l-citrulline can synthesize $\mathrm{NO}{ }^{\bullet}$ by NOS using NADPH and $\mathrm{O}_{2}$ as co-substrates [15] (Figure 1).

$\mathrm{H}_{2} \mathrm{O}_{2}$, a nonradical molecule, can be reduced by multiple oxidases, such as myeloperoxidase. The reaction of $\mathrm{H}_{2} \mathrm{O}_{2}$ is catalyzed with chloride ions $(\mathrm{Cl})$ by this lysosomal enzyme to form hypochlorous acid ( $\mathrm{HOCl}$ ) in neutrophils and monocytes, which allow host defense and pathogen degradation [16]. In the presence of metal ions, it can also be reduced to - $\mathrm{OH}$ by Fenton or Haber-Weiss reactions [17]. These -OH are highly reactive and have an extremely short half-life of $10^{-9} \mathrm{~s}$. They can react rapidly with any oxidizable molecule that they encounter [18] (Figure 1). For instance, they can abstract $\mathrm{H}$ atoms from unsaturated lipids (LH) and initiate lipid peroxidation that induces oxidative degradation of lipids, resulting in cell damage [19]. 


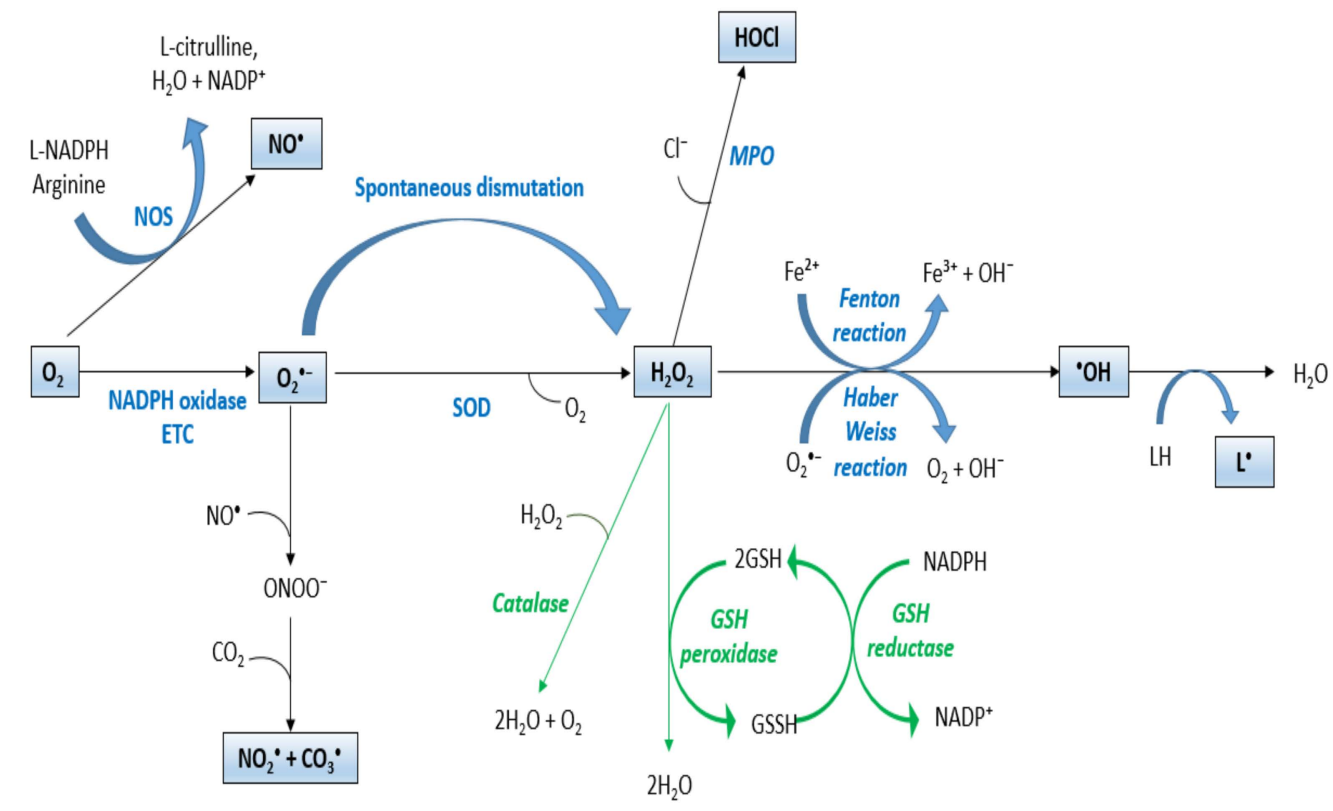

Figure 1. ROS production. ETC: electron transport chain; SOD: superoxide dismutase; MPO: myeloperoxidase; $\mathrm{NO}^{\bullet}$ : nitric oxide; NOS: nitric oxide synthase; $\mathrm{ONOO}^{-}$: peroxynitrite; $\mathrm{O}_{2}{ }^{\bullet-}$ : superoxide anion; $\mathrm{H}_{2} \mathrm{O}_{2}$ : hydrogen peroxide; ${ }^{\bullet} \mathrm{OH}$ : hydroxyl radical; NADP: nicotinamide adenine dinucleotide phosphate; HOCL: hypochlorous acid; GSH: glutathione; LH: unsaturated lipid; $\mathrm{L}^{\bullet}$ : lipid radical.

\subsection{Redox Homeostasis}

ROS are required for organism survival since they play crucial functions in various physiological processes, such as apoptosis [20], immune response [21], differentiation [22], regulation of signaling pathways [23], and reproduction [24]. On the other hand, ROS can be signaling molecules and be involved in the inhibition or induction of cell proliferation, apoptosis, and necrosis [25]. The human organism possesses several antioxidant mechanisms that can inhibit the uncontrolled production of free radicals and their reaction with biological structures, or modulate and counteract their effects in order to maintain redox homeostasis. These mechanisms include different scavengers, such as hydrophilic scavengers (ascorbate and glutathione) that are found in mitochondria, cytosolic, and nuclear aqueous compartments. Ergothioneine scavengers and hydrophobic scavengers include vitamin $\mathrm{E}$ and carotenoids ( $\beta$-carotene), which inhibit lipid peroxidation in cell membranes [26]. There are also different enzymatic proteins, such as SOD [27], CAT [28], and GPx [29], having a key role in the protection against the malignant effects of oxidative stress. For instance, SOD catalyzes the superoxide anion dismutation and produces $\mathrm{H}_{2} \mathrm{O}_{2}$ and $\mathrm{O}_{2}$ [27]. CAT is an enzyme that is located in the peroxisome. It catalyzes the reduction in $\mathrm{H}_{2} \mathrm{O}_{2}$ to $\mathrm{H}_{2} \mathrm{O}$ and $\mathrm{O}_{2}$ when $\mathrm{H}_{2} \mathrm{O}_{2}$ is present at high titers in the cell [28]. GPx is an enzyme that is located in the cell cytoplasm and mitochondria. It catalyzes the reduction in $\mathrm{H}_{2} \mathrm{O}$ to $\mathrm{H}_{2} \mathrm{O}_{2}$ by the oxidation of reduced GSH to GSSH [29]. GR is a cytosolic protein that restores intracellular GSH by reducing glutathione disulfide (GSSG) using NADPH [30] (Figure 1).

Redox homeostasis imbalance with enhanced ROS production and reduced antioxidant activity can damage cells and tissues and lead to various pathologies. In addition, the abnormal accumulation of ROS can alter the structural and functional properties of carbohydrates, nucleic acids, lipids, and proteins [1]. Free radicals can react with amino acids and induce cross-linking, aggregations, and structural disturbance in proteins. They can also directly damage DNA by creating cross-links and altering nucleotide bases and deoxyribose sugars [1]. Hydroxyl radicals can induce lipid peroxidation, which damages the membrane structure and alters its fluidity and function [31]. Radicals can also oxidize 
mono and polysaccharides and induce their polymerization [1]. These alterations can lead to various pathologies, including cancer.

\section{ROS Signaling Pathways in Cancer}

ROS are found to be expressed at high levels in various cancer cells. They are highly implicated in carcinogenesis and can favor tumor progression directly by causing DNA damage, or indirectly by the alteration of different signaling pathways implicated in the cell cycle, cell proliferation, cell survival, apoptosis, etc (Figure 2). On signaling pathways, the most significant effects of oxidative stress were noted in MAP kinase, phosphoinositide 3-kinase (PI3K), NF-kB pathways, and HIF-1 $\alpha$ that is also activated [32].

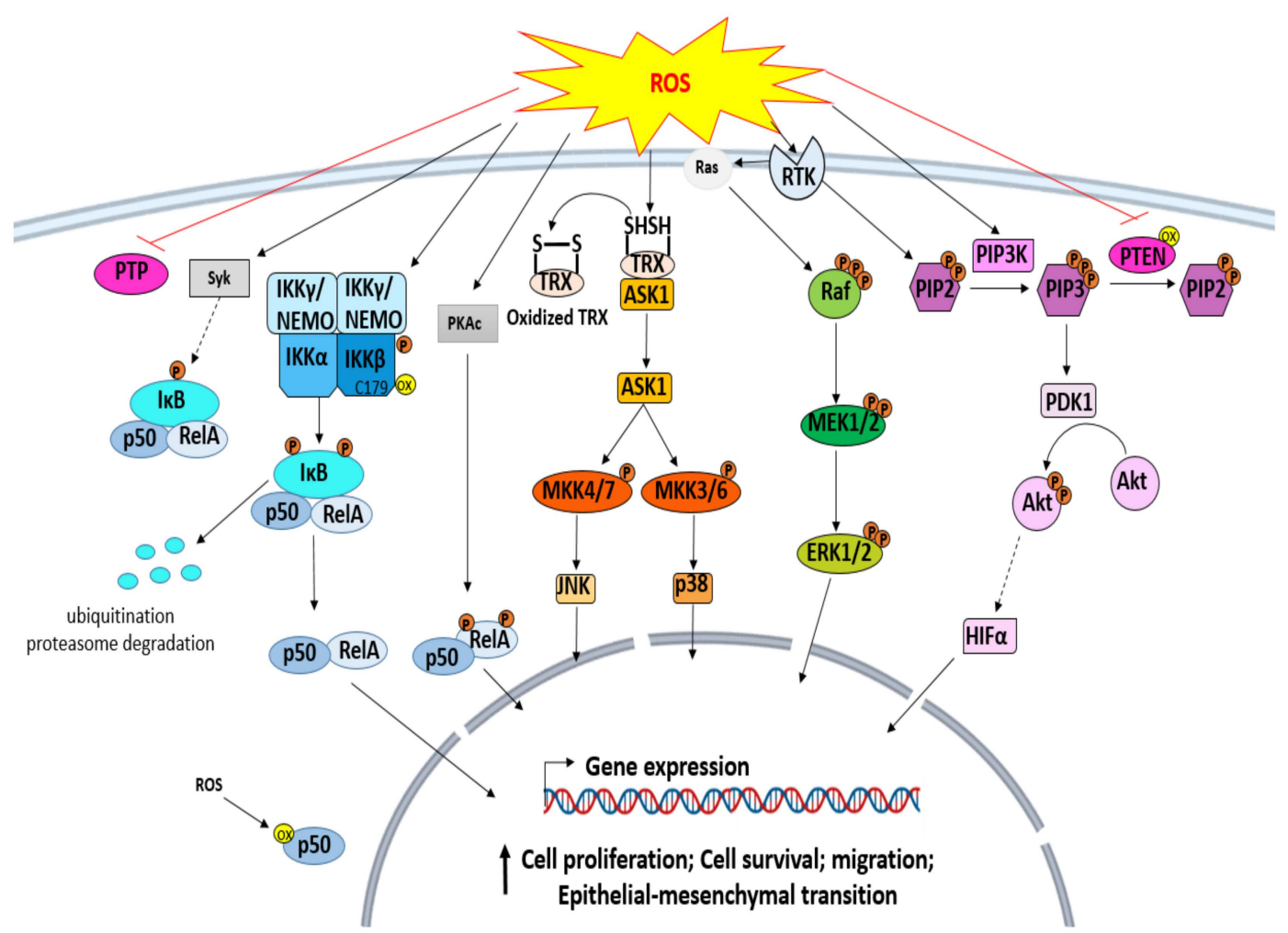

Figure 2. Oxidative-stress-induced signaling pathways in cancer.

\subsection{ROS and Protein Tyrosine Kinase (PTK)}

Protein phosphorylation is affected by PTKs by catalyzing, in protein substrates, the transfer of phosphate from ATP to tyrosine residues. They play a vital role in intracellular signaling, and their catalytic function can be regulated by other different PTKs or protein tyrosine phosphatases (PTPs). This regulation can also be modulated by environmental chemicals or oxidative stress. ROS upregulate the catalytic activities of PTKs through the inactivation of PTPs. They can also directly oxidize SH groups of specific conserved cysteine residues on PTKs or produce disulfide-bonded dimers on PTK proteins [33]. Furthermore, the activation of the cell death or cell cycle depends on the generated ROS levels. Low levels of ROS may lead to cell cycle activation via the upregulation of PTKs, including MAPK proteins, such as serine/threonine kinases, ERK, and transcription factors. Slightly increased levels of ROS induce death through a cascade of signals, started by the activation of Ask1, a member of the MAPK family that activates different signaling pathways, including Bax/BH3, JNK/p35 MAPK, caspases, and cytochrome C. High levels of ROS induce necrosis by damaging mitochondria [33]. 


\subsection{Mitogen-Activated Protein Kinases (MAPKs) Signaling Pathway}

MAPKs, a family of serine-threonine protein kinases, include ERKs, stress-activated MAPKs, JNKs, and p38 MAPKs. These molecules transduce signals from the cell surface to the nucleus through a cascade of phosphorylation on their threonine and tyrosine residues. They also regulate invasion, apoptosis, differentiation, and cell proliferation [34]. The deregulation of the MAPK signaling pathway is highly involved in human cancer, and oxidative stress is among the crucial factors that lead to this deregulation and induce carcinogenesis. The high levels of ROS can activate these kinases and promote cell migration, proliferation, survival, and epithelial-mesenchymal transition [35]. ROS may directly oxidize tyrosine kinase receptors, which induce activation of Ras-GTPase. Ras phosphorylates Raf, a MAP3K that activates, in turn, ERK via MAP/ERK kinase (MEK) [34]. ROS also oxidize thioredoxin, which dissociates from ASK-1, a MAP3K, and, therefore, ASK-1 activates MKK3, MKK4, MKK6, and MKK7. Moreover, MKK3 and MKK6 phosphorylate and activate p28 MAPK, while MKK4 and MKK7 phosphorylate JNK protein, which is involved in cancer cell apoptosis [34].

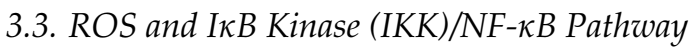

$\mathrm{NF}-\mathrm{KB}$, a transcription factor regulating the expression of various genes, is involved in various physiological processes, including response to stress, cell survival, immune defense, etc. In the cytoplasm, it is present in an inactive complex form coupled to the inhibitory protein IKB. It can be activated through a classical (canonical) or alternative (noncanonical) pathway [36]. The canonical NF- $\kappa B$ pathway is mediated by a NEMO-dependent IKK and is activated by proinflammatory signals, such as danger-associated molecular patterns (DAMPs), cytokines, and pathogen-associated molecular patterns (PAMPs). The activation by these agents leads to the activation of NEMO-containing kinase complexes, the phos-

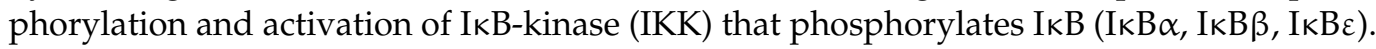
The phosphorylation of $I_{\kappa} B$ induces its degradation and ubiquitination in the proteasome, which leads to the translocation of NF- $\mathrm{kB}$ into the nucleus. NF- $\mathrm{kB}$ then binds to DNA control elements and activates gene expression [36]. Besides, the noncanonical pathway is mediated by a NEMO-independent IKK1 kinase complex and is activated through a cascade of signals that activate NIK/IKK1 and result in the degradation of IKb $\delta$ and the translocation of RelB: p52, RelB: p50, and RelA: p50 dimers to the nucleus to regulate gene expression [36]. ROS can modulate the expression of genes that promote carcinogenesis by altering the NF- $\mathrm{kB}$ signaling pathway. They can regulate the NF- $\mathrm{kB}$ pathway, both positively or negatively. They inactivate NF-kB function directly through the oxidation of IKK $\beta$ on cysteine 179 , or the oxidation of p50 on cysteine 62 located in RHD, and, therefore, inhibit NF- $\mathrm{KB}$ binding to DNA; or indirectly through the deregulation of other proteins involved in NF- $\mathrm{kB}$ expression. For instance, ROS can activate the phosphorylation of RelA on Ser-276 by PKAc, which activates NF- $\mathrm{kB}$ [37]. $\mathrm{H}_{2} \mathrm{O}_{2}$ can also activate NF- $\mathrm{kB}$ through spleen tyrosine kinase (Syk)-mediated tyrosine phosphorylation of I $\mathrm{k} \alpha$ [38].

\subsection{ROS and Phosphoinositide 3 Kinases (PI3K)/Akt Signaling Pathway}

PI3Ks, a group of plasma-membrane-associated lipid kinases, contains two regulatory subunits (p85 and p55) and a catalytic subunit (p110) [39]. They catalyze the conversion of phosphatidylinositol-4,5-biphosphate (PIP2) to phosphatidylinositol-3,4,5-triphosphate (PIP3), which allows the phosphorylation of Akt through phosphoinositide-dependent protein kinase (PDK1) and the activation of its downstream signaling. PI3K/Akt signaling is negatively regulated by the tumor suppressor gene PTEN, which converts PIP3 into PIP2 and reduces cell proliferation and migration [40]. Oxidative stress mediates PI3K/Akt signaling activation directly through the inhibition of phosphatases, such as PTEN, or indirectly through the activation of Akt by other proteins. PTEN activity is highly affected by redox state $[40,41]$. It can be inactivated directly through the oxidation of its cysteine residues, which enhance the expression levels of PIP3 and activate AKT signaling and the 
expression of genes involved in cell survival [42]. In addition, ROS can indirectly activate Akt through an EGFR/PI3K-dependent pathway [43].

\subsection{ROS and Hypoxia-Inducible Factor 1 (HIF-1) Signaling in Cancer}

HIF-1, a heterodimeric transcription factor, mediates the response to hypoxia. It controls the expression of different genes implicated in apoptosis, cell cycle, cellular metabolism, and angiogenesis. It is overexpressed in various ROS-induced cancers, such as breast, ovarian, and prostate cancer. The elevated HIF-1 expression is induced and stabilized by ROS in hypoxic tumors [44]. It was demonstrated that high expression of epidermal growth factor (EGR) in ovarian cancer induces $\mathrm{H}_{2} \mathrm{O}_{2}$ production, which activates PI3K/Akt/p70S6K1. Activated p70S6K1 stimulates HIF-1a expression and, consequently, increases the expression of VEGF that mediates angiogenesis [45].

\section{Oxidative-Stress-Induced Epigenetic Instability in Cancer}

Cancer is one of the major health issues around the globe. It occurs due to various genetic and epigenetic alterations. These alterations occur as a result of various internal factors (e.g., DNA polymerase errors, oxidative stress, spontaneous deamination, etc.) [32,46] and external factors (e.g., stress, radiation, microbes, etc.) $[47,48]$. Genetic alterations, including chromosomal aberrations, amplification, mutations, deletions, insertions, etc., deregulate the expression of tumor suppressor genes (TSGs), DNA repair genes, and oncogenes, which lead to abnormal cell growth. Epigenetic refers to the modification of gene expression and chromatin structure without any change in DNA sequence. It is a crucial mechanism that ensures many physiological processes, including gene imprinting, differentiation, reproduction, cell division, etc. However, a deregulation of this mechanism is associated with different pathologies. Epigenetic instability is one of the key characteristics of cancer. It involves the alteration of chromatin remodeling, the deregulation of noncoding RNAs (ncRNAs), and histone modifications, as well as the modification of DNA methylation status [49]. These modifications alter gene expression, replication, and DNA repair.

Oxidative stress is one of the crucial factors in cancer development. It can induce genetic damage or alter epigenetic mechanisms. It can also induce various types of DNA damage and modifications in DNA structure, including deletions, strand breaks, chromosomal aberrations, base and sugar lesions, DNA-protein cross-links, etc. Furthermore, it can induce alterations to the cancer epigenome, including DNA methylation, deregulation of lncRNA expression, and modification of histones and chromatin remodelers [50]. Furthermore, oxidative stress can oxidize proteins and lipids and generate other reactive products that can damage DNA [50].

\subsection{Oxidative Stress and DNA Methylation}

DNA methylation is an essential gene regulation mechanism that causes transcription repression. It occurs in sequences with a high frequency of CG dinucleotide repeats, known as $\mathrm{CpG}$ islands, which can be found in the promoter or non-promoter regions. Different enzymes mediate DNA methylation, including DNA methyltransferases (DNMTs), methylCpG binding proteins (MBPs), and methyl CpG binding protein 2 (MeCP2). DNMTs form 5-methylcytosine $(5 \mathrm{mC})$ by adding a methyl group to the $5^{\prime}$ carbon of cytosine nucleotides. MBPs and MeCP2 have the capacity to discriminate between methylated and unmethylated $\mathrm{CpG}$ dinucleotides. They bind to methylated $\mathrm{CpG}$ sites and recruit chromatin remodelers and histone deacetylases (HDACs) that remove the acetyl group from acetylated lysine residues of histone proteins and inactivate gene expression [51,52]. Hypermethylation of $\mathrm{CpG}$ islands located on tumor suppressor gene promoters (TSGs) or DNA repair gene promoters induces inactivation of their expression [53]. In contrast, hypo- or demethylation of $\mathrm{CpG}$ islands that are located on oncogene promoters or nonpromoter regions of repetitive elements, transposable elements, and retroviruses induces an abnormal activation of gene expression and genome instability [54]. 
Oxidative stress induces the oxidation of different oligonucleotides, including guanine, thymine, and $5 \mathrm{mC}$. The oxidation of guanine to 8-oxoguanine (8-oxoG) represents the major form of DNA damage, and is considered a biomarker of oxidative damage. This oxidation replaces the 8-proton with an oxygen atom and converts the N7 position of the guanine from an H-bond acceptor to an H-bond donor, which can inhibit the methylation of the cytosine residue adjacent to that of 8-oxoG residue [55]. Furthermore, 8-oxoG has a mutagenic potential, since it allows the misincorporation of deoxyadenosine- $5^{\prime}-$ monophosphate (dAMP) and dCMP during replication and allows the generation of GCAT transversion mutations [56,57]. Additionally, ROS can also generate $O^{6}$-methylguanine that inhibits methylation of the adjacent cytosine by inhibiting the binding of methyltransferases and, therefore, induces hypomethylation [58]. Moreover, the 5-methyl group of $5 \mathrm{mC}$ allows MBPs to discriminate between methylated and unmethylated DNA. However, its hydroxylation can generate 5-formylcytosine, 5-hydroxymethylcytosine ( $\mathrm{HmC})$, or 5 -carboxycytosine, which inhibit the binding of MBPs and alter epigenetic mechanisms. In addition, oxidation of the methyl group of thymine generates 5-hydroxymethyluracil (HmU), which interferes with transcription factor binding [55].

ROS can also alter the expression of proteins by increasing the expression of chromatin remodelers involved in DNA methylation. For instance, ROS increases the expression of Snail, a methyl-CpG binding protein that recruits DNA methyltransferase 1 (DNMT1) and histone deacetylase 1 (HDAC1), and induces the hypermethylation of E-cadherin, a tumor suppressor gene. The downregulation of E-cadherin expression is correlated with epithelial-to-mesenchymal transition, metastasis, tumor progression, and poor prognosis in hepatocellular carcinoma [59]. In addition, the increased expression of DNMT1 and HDAC1 induced by ROS can inhibit the expression of different tumor suppressor genes, such as caudal-related homeobox-1 (CDX1), that are related to the progression of colorectal cancer [60]. Furthermore, studies have shown that oxidative stress can mediate the hypermethylation and inactivation of the tumor suppressor gene $p 16 I N K 4 A$, which enhances the malignant progression of renal cell carcinomas (RCCs) [61].

\subsection{Oxidative Stress and Histone Modification}

Histones are crucial structural proteins that ensure DNA packaging in the nucleus, regulate the accessibility of DNA to transcription factors, restriction enzymes, etc., and modulate transcription, replication, and repair $[62,63]$. They undergo different modifications, commonly acetylation, deacetylation, methylation, and demethylation. Different enzymes, such as histone acetyltransferases (HAT), bromodomain and extra terminal domain (BET) proteins, and histone deacetylases (HDAC), regulate histone acetylation and deacetylation. HATs catalyze the transfer of an acetyl group from acetyl-CoA to the $\varepsilon$-amino group of lysine residues at histone proteins, which reduce the affinity of histones to DNA, release the chromatin, and activate DNA transcription. In contrast, BET proteins (BRD2/3 and 4) recognize acetylated histone lysine and recruit HDACs that remove the acetyl group from lysine and increase the affinity of histones to DNA, and, hence, compact the chromatin and repress DNA transcription [62,64]. In addition, different enzymes regulate histone methylation and demethylation, such as histone demethylases (HDMs) and histone methyltransferases (HMTs). HMTs transfer the methyl group from S-adenosyl methionine (SAM) to arginine $(\mathrm{R})$ and lysine $(\mathrm{K})$ residues. In contrast, HDMs remove the methyl group from $R$ and $K$ residues of histones.

Oxidative stress can modify the acetylation and methylation status of histone molecules by altering the enzymes that are involved in chromatin remodeling. Hydrogen peroxide can induce the delocalization of a silencing complex containing DNMT1, DNMT3B, and members of polycomb repressive complex 4 (PRC4) from non-GC-rich to GC-rich areas. This complex induces different changes in histone marks. For instance, SIRT1, a member of PRC4 reduces histone active marks, such as 3MeK4H3 and AcK16H4. PcG component of EZH2 activates the expression of histone repressive marks, such as H3K27me3. This complex can also increase DNA methylation and gene silencing in colon cancer [65]. 


\subsection{Oxidative Stress and miRNAs}

MicroRNAs (miRNAs) are tiny noncoding RNAs measuring about 18 to 25 nucleotides. They have a major role in the post-transcriptional regulation of gene expression [66] and they are involved in many physiological mechanisms, including apoptosis, cell cycle regulation, differentiation, proliferation, development, stress response, etc. [67]. They are located at different DNA regions, including noncoding genomic regions, intronic or exonic regions of coding genes [67], fragile sites, common breakpoint regions, minimal regions of amplification, and minimal regions of loss of heterozygosity [68]. miRNAs are transcribed in the nucleus to primary miRNAs (pi-miRNAs) by RNA polymerase II or III. Pi-miRNAs are then polyadenylated, capped, and cleaved in the nucleus by a complex involving drosha ribonuclease and DGGR8, forming hairpins called precursor miRNAs that are exported by exporting- 5 to the cytoplasm. Once in the cytoplasm, a ribonuclease Dicer cleaves the pre-miRNA and generates a double-stranded RNA molecule. One of the strands is degraded, while the second one is stably associated with RNA-induced silencing complex (RISC), and it binds to a homologous $3^{\prime}$ untranslated region ( $3^{\prime}$-UTR) of an mRNA in order to block its translation or favor its degradation [69].

The levels of miRNA in tumor cells are altered, and oxidative stress is one of the factors that contributes to this alteration. Oxidative stress can influence miRNA expression by altering the expression of enzymes involved in miRNA biogenesis, inducing epigenetic changes, such as methylation, or directly damaging miRNA genes or mature sequences [70]. For instance, ROS can inhibit $m i R-199 \alpha$ and $m i R-125 b$ gene expression in ovarian cancer by increasing hypermethylation of their promoters via DNMT1. The low expression of these miRNAs induces overexpression of the epidermal growth factor receptor family, including ERBB2/3, that is associated with cancer development, poor prognosis, and drug resistance [71]. In addition, ROS promote gastric cancer by upregulating the expression of miR-21, which subsequently downregulates the expression of programmed cell death 4 protein (PDCD4), a tumor suppressor gene that inhibits tumor progression and neoplastic transformation. The inhibition of this gene increases metastasis, tumor invasion, and cell transformation [72]. ROS also induce overexpression of miR-500a-5p and decreased expression of thioredoxin reductase 1 (TXNRD1) and nuclear factor, erythroid-2-like 2 (NFE2L2) that are involved in cellular antioxidant response. This deregulation is associated with poor prognosis in breast cancer [73]. Similarly, miRNA also regulates ROS production in cancer by targeting proteins implicated in the production or elimination of ROS [70]. A study has demonstrated that miR-155 is upregulated by the oncogene K-Ras through MAPK-AP1 and NF-kB pathways in pancreatic cancer. This upregulation promotes ROS levels through the inhibition of Foxo3a expression, which leads to decreased expression levels of SOD2 and catalase antioxidants and allows for tumor progression [74].

\section{Antioxidant Protective Effects of Natural Compounds}

\subsection{In Vivo Preclinical Investigations}

\subsubsection{Flavonoids}

The antioxidant activity of flavonoids (Table 1) was described in numerous works using several in vivo models [75-91]. Indeed, Yue et al. [91] investigated the protective effect of apigenin against $\mathrm{CCl}_{4}$-induced hepatotoxicity in mice. The results showed that this flavonoid significantly protected liver tissue by elevating the SOD, GSH, GSH-Px, and CAT levels, and reducing MDA. The potential of this compound was tested in streptozotocininduced diabetic mice in in vivo studies conducted by Mao et al. [82] and Liu et al. [81]. The results demonstrated that apigenin suppressed oxidative stress by various mechanisms, such as reducing the malondialdehyde content and increasing GSH and SOD levels. 
Table 1. In vivo antioxidant activity of flavonoids.

\begin{tabular}{|c|c|c|c|}
\hline Compounds & Experimental Approach & Key Results & Refs \\
\hline Apigenin & CCl4-induced hepatotoxicity in mice & $\begin{array}{l}\text { SOD, CAT, GSH-Px, and GSH levels increased. } \\
\text { MDA level was decreased. }\end{array}$ & [91] \\
\hline Apigenin & Kainic acid (KA)-induced excitotoxicity & GSH levels were increased. & [78] \\
\hline Apigenin & STZ-induced diabetic cardiomyopathy & $\begin{array}{l}\text { SOD and GPx activity were increased. } \\
\text { Decreased GSH levels. }\end{array}$ & [81] \\
\hline Apigenin & $\mathrm{H}_{2} \mathrm{O}_{2}$-induced rat hepatic stellate cells & $\begin{array}{c}\text { SOD and GSH levels were enhanced. } \\
\text { ROS, MDA, and NO levels were inhibited. }\end{array}$ & [83] \\
\hline Apigenin & $\begin{array}{l}\text { Diabetes-associated cognitive decline a } \\
\text { diabetic rat model }\end{array}$ & $\begin{array}{l}\text { Decreased the MDA content. } \\
\text { Increased SOD activity and GSH level. } \\
\text { Inhibited the activities of cNOS and iNOS. }\end{array}$ & [82] \\
\hline Apigenin & $\begin{array}{c}\text { Myocardial ischemia/reperfusion injury in } \\
\text { mice }\end{array}$ & $\begin{array}{l}\text { Significantly decreased MDA. } \\
\text { Elevated SOD activity. }\end{array}$ & \\
\hline Catechin & Subacute chlorpyrifos-induced oxidative stress & $\begin{array}{l}\text { Reduced MDA content. } \\
\text { SOD, CAT, and GPx activities were increased. }\end{array}$ & [75] \\
\hline Catechin & Type 2 diabetic erythrocytes & $\begin{array}{l}\text { Decreased MDA. } \\
\text { Increased GSH. }\end{array}$ & [84] \\
\hline Hesperetin & Acetaminophen-induced hepatotoxicity & $\begin{array}{c}\text { Increased levels of glutathione. Increased SOD } \\
\text { and CAT activities. } \\
\text { Reduced MDA levels. }\end{array}$ & [88] \\
\hline Hesperetin & Streptozotocin-induced diabetic in rat & $\begin{array}{c}\text { Increased GSH. } \\
\text { Improved CAT, SOD, and GPx. } \\
\text { Decreased levels of MDA. } \\
\text { Reduced protein carbonyl. }\end{array}$ & [86] \\
\hline Quercetin & Subacute-chlorpyrifos-induced oxidative stress & $\begin{array}{l}\text { Decreased malondialdehyde levels. } \\
\text { Enhanced SOD, CAT, and GPx. }\end{array}$ & [75] \\
\hline Quercetin & $\begin{array}{l}\text { Streptozotocin-nicotinamide-induced diabetic } \\
\text { rats }\end{array}$ & $\begin{array}{l}\text { Improved SOD, CAT, GPx. } \\
\text { Increased mRNA expression levels. } \\
\text { Ameliorated MDA levels. }\end{array}$ & [90] \\
\hline Quercetin & $\begin{array}{l}\text { Streptozotocin-nicotinamide-induced diabetic } \\
\text { rats }\end{array}$ & Improved cardiac SOD-1, CAT, and GPx-1. & [85] \\
\hline Quercetin & Myocardial ischemia reperfusion (IR) injuries & $\begin{array}{c}\text { Reduced MDA content. } \\
\text { Increased the activities of GSH, SOD, CAT, } \\
\text { GSH-Px, GR. }\end{array}$ & [80] \\
\hline Quercetin & $\begin{array}{l}\text { Sodium-azide-induced hepatic and splenic } \\
\text { oxidative stress in vivo }\end{array}$ & $\begin{array}{l}\text { SOD and GPx activities were significantly } \\
\text { increased. } \\
\text { Considerably reduced MDA concentrations. }\end{array}$ & [87] \\
\hline Rutin & Intestinal toxicity induced by methotrexate & $\begin{array}{l}\text { Decreased TBARS and protein carbonyl. } \\
\text { Increased SOD, catalase, and GSH. }\end{array}$ & [77] \\
\hline Rutin & Alloxan-induced diabetic nephropathy & $\begin{array}{l}\text { Increased SOD and catalase. } \\
\text { Reduced lipid peroxidation. } \\
\text { Downregulated endoplasmic reticulum stress } \\
\text { markers GRP78 and CHOP. }\end{array}$ & [76] \\
\hline Rutin & Gastric lesions induced by $50 \%$ ethanol & $\begin{array}{l}\text { Significantly increased GSH-Px activity. } \\
\text { Decreased the levels of thiobarbituric acid. }\end{array}$ & [79] \\
\hline Resveratrol & Ethanol-induced oxidative stress in vivo & $\begin{array}{l}\text { Increased SOD activity. } \\
\text { Increased catalase. } \\
\text { Increased glutathione peroxidase. }\end{array}$ & [92] \\
\hline
\end{tabular}


Table 1. Cont.

\begin{tabular}{|c|c|c|c|}
\hline Compounds & Experimental Approach & Key Results & Refs \\
\hline Resveratrol & $\begin{array}{l}\text { Oxidative stress cardiomyopathy induced by } \\
\text { doxorubicin }\end{array}$ & $\begin{array}{l}\text { Reduced MDA content. } \\
\text { Promoted SOD, CAT, and GPx activities. } \\
\text { Increased GSH. }\end{array}$ & [93] \\
\hline Resveratrol & Lipopolysaccharide-induced oxidative stress & $\begin{array}{l}\text { Significantly reduced the level of TBARS. } \\
\text { Significantly increased glutathione level and } \\
\text { the superoxide dismutase. }\end{array}$ & [94] \\
\hline Resveratrol & $\begin{array}{l}\text { Hyperglycemia-induced renal tubular } \\
\text { oxidative stress damage }\end{array}$ & $\begin{array}{l}\text { Prevented the SOD activity downregulation } \\
\text { and MDA upregulation. } \\
\text { Significantly increased CAT levels. } \\
\text { Modulates the SIRT1/FOXO3a pathway. }\end{array}$ & [95] \\
\hline Resveratrol & $\begin{array}{l}\text { Murine model of lipopolysaccharide } \\
\text { (LPS)-induced pulmonary fibrosis }\end{array}$ & $\begin{array}{l}\text { Decreased MDA levels. } \\
\text { Increased total antioxidant activity, superoxide } \\
\text { dismutase, and catalase activities. }\end{array}$ & [96] \\
\hline
\end{tabular}

The study of Demir et al. [75] found that oral administration of catechin $20 \mathrm{mg} / \mathrm{kg}$ ameliorated chlorpyrifos-induced oxidative stress in rat erythrocytes by the reduced malondialdehyde levels and elevated SOD, CAT, and GPx activities. The mechanism by which this compound elevated the levels of enzymatic and nonenzymatic antioxidant activities may involve the dismutation of $\mathrm{O}_{2}$.- and the decomposition of hydrogen peroxide, and may represent an aspect of the cellular response to increasing the levels of reactive oxygen species. On the other hand, oral administration of $50 \mathrm{mg} / \mathrm{kg}$ attenuated inappropriate alterations of the oxidative stress that was induced by STZ in mice by reducing malondialdehyde content, ROS, and protein carbonyl as a marker of lipid peroxidation and enhancing antioxidants, including SOD, CAT, and GPx activities [86]. Recently, Wan et al. [88] reported that injection of acetaminophen in mice induced acute liver injury by the formation of ROS and the perturbation of cellular antioxidant defense. Moreover, hesperetin pretreatment attenuated this oxidative stress, which was indicated by increasing antioxidative molecule production (GSH, SOD, and CAT) and decreased MDA levels. The antioxidant activity of this flavonoid may be due to neutralizing ROS and strengthening the defense system of the cell, including ERK/Nrf2 signaling.

Quercetin has been known as an interesting antioxidant compound. Its antioxidant efficacy was demonstrated in streptozotocin-induced diabetic rats, and chlorpyrifos- and $\mathrm{NaN}_{3}$-induced oxidative stress in rats. The data from these studies showed that quercetin decreased MDA levels $[75,87]$, increased sperm SOD, CAT, and GPx activities and their mRNA expression levels [85,90], and elevated GSH, GSH-Px, and GR activity [80].

Rutin also showed a potent antioxidant effect. La Casa and collaborators [79] studied the gastroprotective effect of this compound using ethanol (50\%) to induce gastric lesions. They reported that rutin at a concentration of $200 \mathrm{mg} / \mathrm{kg}$ has a protective activity. It decreased the gastric mucosal damage and elevated the antioxidant enzymatic glutathione peroxidase. At the same time, our results revealed an anti-lipoperoxidant effect via decreasing the levels of TBA [79]. In addition to attenuating oxidative stress, rutin downregulated endoplasmic reticulum stress markers GRP78 and CHOP in alloxan-induced diabetic nephropathy [76].

The antioxidant effect of resveratrol was also evaluated in vivo using ethanol [92], doxorubicin [93], lipopolysaccharide [94], and hyperglycemia [95] induced oxidative stress in mice. The results of different works reported that this natural compound exhibited potent antioxidant activity via several mechanisms, including the decrease in the content of malondialdehyde, promoting the activities of SOD, CAT, and GSH-Px. It also modulates the SIRT1/FOXO3a pathway by elevating SIRT1deacetylase activity. 


\subsubsection{Phenolic Acids}

Numerous reports have evaluated the antioxidant activities of phenolic acids (Table 2) [97-108]. In a study reported by Tolba et al. [107], caffeic acid showed a potential antioxidant activity by enhancing glutathione peroxidase content and SOD activity and significantly decreasing femur bone MDA in glucocorticoid-induced osteoporosis in vivo. Shen and collaborators studied the antioxidant effect of $p$ coumaric acid on a high-fat diet (HFD) mice model. They found that p-coumaric acid can increase the expression of Nrf2, Gpx, SOD-1, and HO-1. In addition to these effects, p-CA elevated CAT level in serum, total antioxidant capacity, and GSH-Px levels in the liver, and ameliorated lipid peroxidation [104].

Table 2. In vivo antioxidant activity of phenolic acid.

\begin{tabular}{|c|c|c|c|}
\hline Compounds & Experimental Approach & Key Results & Refs \\
\hline Caffeic acid & $\begin{array}{l}\text { Glucocorticoid-induced osteoporosis } \\
\text { in vivo }\end{array}$ & $\begin{array}{l}\text { Elevated glutathione peroxidase content } \\
\text { and superoxide dismutase. } \\
\text { Significantly decreased malondialdehyde } \\
\text { levels. }\end{array}$ & [107] \\
\hline Caffeic acid & $\begin{array}{l}\text { Medium-term rat hepatocarcinogenesis } \\
\text { model }\end{array}$ & Decreased lipid peroxidation. & [98] \\
\hline p-Coumaric acid & High-fat diet (HFD) mice model & $\begin{array}{l}\text { Elevated CAT, total antioxidant capacity, } \\
\text { and GSH-Px levels. }\end{array}$ & [104] \\
\hline Ferulic acid & Cisplatin-induced ototoxicity & $\begin{array}{l}\text { Increased SOD and GPx activities. } \\
\text { Reduced MDA levels. }\end{array}$ & {$[100,102,108]$} \\
\hline Ferulic acid & Acetaminophen-induced hepatotoxicity & $\begin{array}{c}\text { Enhanced superoxide dismutase and } \\
\text { catalase activities. } \\
\text { Increased GSH-Px levels. }\end{array}$ & [108] \\
\hline Ferulic acid & Formaldehyde-induced hepatotoxicity & $\begin{array}{l}\text { Increased CAT, GPx content, and SOD } \\
\text { activities. } \\
\text { Decreased malondialdehyde content. }\end{array}$ & [100] \\
\hline Gallic acid & Balb/c mice with post-stroke depression & $\begin{array}{l}\text { Increased SOD and CAT activities. } \\
\text { Elevated glutathione peroxidase content. } \\
\text { Decreased TBARS levels. }\end{array}$ & [103] \\
\hline Gallic acid & $\begin{array}{l}\text { Cerebral ischemia/reperfusion-induced } \\
\text { by middle cerebral artery occlusion }\end{array}$ & Reduced MDA levels. & [105] \\
\hline Rosmarinic acid & Aluminum-induced oxidative stress & $\begin{array}{c}\text { Increased GSH concentration. } \\
\text { Decreased MDA concentration. } \\
\text { Increased CAT and SOD activities. }\end{array}$ & [97] \\
\hline Rosmarinic acid & $\begin{array}{l}\text { High-fat diet and streptozotocin-induced } \\
\text { diabetic rats. }\end{array}$ & $\begin{array}{l}\text { Elevated the levels of vitamin C, vitamin } \\
\text { E, and GSH. } \\
\text { Elevated SOD, CAT, and GPx activities. } \\
\text { Decreased lipid peroxide, AOPP, and } \\
\text { protein carbonyl levels. }\end{array}$ & [101] \\
\hline Rosmarinic acid & $\begin{array}{l}\text { Lipopolysaccharide-induced memory } \\
\text { impairment }\end{array}$ & $\begin{array}{c}\text { SOD activity increased. } \\
\text { GSH levels reduced. } \\
\text { Decreased lipid peroxidation in the brain. }\end{array}$ & [106] \\
\hline Vanillic acid & $\begin{array}{l}\text { Ischemia-reperfusion-induced oxidative } \\
\text { stress in isolated rat heart }\end{array}$ & $\begin{array}{c}\text { Decreased MDA. } \\
\text { Elevated SOD, CAT, and GPx activities. }\end{array}$ & [99] \\
\hline
\end{tabular}

Ferulic acid is another phenolic acid that exhibits a protective activity against cisplatin-, acetaminophen-, and formaldehyde-induced oxidative stress. The authors showed that oral administration of ferulic acid inhibited the expression of cytochrome P450 2E1, increased SOD, GPx, and CAT activities, and GSH levels. It also protected lipid peroxidation by decreasing MDA levels [100,102,108]. 
In another work, Nabavi et al. [103] investigated the antioxidant effect of gallic acid in vivo by determination of the SOD and CAT activities, TBARS, and GSH levels for mouse brains. They found that oral administration of GA improved the antioxidant system by increasing SOD and CAT activities and GSH content, as well as decreasing TBARS levels. Govindaraj and Sorimuthu Pillai [101] studied the protective effect of rosmarinic acid on rats with a high-fat diet and streptozotocin-induced diabetic and oxidative stress, and the results demonstrated that this phenolic acid decreased the lipid peroxide, AOPP, and protein carbonyl levels, and increased enzymatic antioxidant (superoxide dismutase and catalase) and nonenzymic antioxidants (GPx, GSH, Vit. C, and Vit. E) in diabetic rats [101]. This result was confirmed by Baranauskaite et al. [97] and Thingore et al. [106], which proved a decrease in MDA concentration and an increase in SOD and CAT activities after treatment with rosmarinic acid. On the other hand, the study of Dianat and their colleagues demonstrated that vanillic acid reduced the malondialdehyde content, as well as elevated SOD, CAT, and GPx activities on ischemia-reperfusion-induced oxidative stress in isolated rat hearts [99].

\subsubsection{Terpenoids}

Terpenoids are volatile compounds that have various biological proprieties, such as antioxidant activity. Indeed, more than 20 works (Table 3) studied this effect in vivo [92-97,109-126].

Table 3. In vivo antioxidant activity of terpenoids.

\begin{tabular}{|c|c|c|c|}
\hline Compounds & Experimental Approach & Key Results & Refs \\
\hline Camphor & Atrazine-induced toxicity & $\begin{array}{l}\text { Increased SOD activity. } \\
\text { Reduced MDA levels. }\end{array}$ & [118] \\
\hline Carvacrol & $\begin{array}{l}\text { N-nitrosodiethylamine-induced liver injury in } \\
\text { mice }\end{array}$ & $\begin{array}{l}\text { Decreased the levels of lipid peroxides. } \\
\text { Elevated superoxide dismutase and catalase } \\
\text { activities. } \\
\text { Significantly increased the activities of GPx, GR, } \\
\text { GSH, G6PD, vitamin (Vit. A), Vit. C and Vit. E. }\end{array}$ & [116] \\
\hline Carvacrol & $\begin{array}{l}\text { Acute myocardial infarction } \\
\text { in mice }\end{array}$ & $\begin{array}{c}\text { Decreased MDA content. } \\
\text { Increased SOD, GSH, and GSH-Px activities. }\end{array}$ & [126] \\
\hline Carvacrol & $\begin{array}{l}\text { Restraint-stress-induced oxidative stress } \\
\text { damage in the brain, liver, and kidney }\end{array}$ & $\begin{array}{c}\text { Reduced MDA content. } \\
\text { Elevated GSH, SOD, GPx, GR, and CAT } \\
\text { activities. }\end{array}$ & [117] \\
\hline Carvacrol & Alloxan-induced diabetic rats & $\begin{array}{l}\text { Reduced malondialdehyde. } \\
\text { Increased significantly glutathione levels. }\end{array}$ & [112] \\
\hline Carvacrol & STZ-induced diabetic rats & $\begin{array}{l}\text { Reduced levels of tissue malondialdehyde. } \\
\text { Increased antioxidant enzymes (SOD and GPx,). }\end{array}$ & [119] \\
\hline Carvacrol & $\begin{array}{l}\text { Weaning-induced intestinal dysfunction in } \\
\text { piglets }\end{array}$ & $\begin{array}{c}\text { Significantly elevated superoxide dismutase and } \\
\text { glutathione peroxidase activities. } \\
\text { Decreased TBARS levels. }\end{array}$ & [122] \\
\hline Carvacrol & Aluminium-induced oxidative stress & $\begin{array}{l}\text { Increased GSH concentration. } \\
\text { Decreased MDA concentration. } \\
\text { Increased CAT and SOD activities. }\end{array}$ & [97] \\
\hline Citral & $\begin{array}{l}\text { Streptozotocin/high-fat-diet-induced diabetic } \\
\text { dyslipidemic rats }\end{array}$ & $\begin{array}{l}\text { Significant reduction in the level of MDA. } \\
\text { Attenuated protein carbonyl content. } \\
\text { Significantly improved the activity of SOD. } \\
\text { Significantly restored the activity of catalase. } \\
\text { Significant increase in Gpx activity. }\end{array}$ & [114] \\
\hline D-limonene & Alloxan-induced diabetic rats & $\begin{array}{l}\text { Reduced malondialdehyde and NO. } \\
\text { Elevated GSH levels. } \\
\text { Increased GPx, CAT, and SOD activities. } \\
\text { Significant elevation in mRNA levels of } \\
\text { superoxide dismutase, catalase, and glutathione } \\
\text { peroxidase activities. }\end{array}$ & [110] \\
\hline
\end{tabular}


Table 3. Cont.

\begin{tabular}{|c|c|c|c|}
\hline Compounds & Experimental Approach & Key Results & Refs \\
\hline Geraniol & Hepatic ischemia reperfusion injury & $\begin{array}{l}\text { Increased GSH levels. } \\
\text { Normalized malondialdehyde. } \\
\text { Decreased Keap1 expression. } \\
\text { Elevated the nuclear accumulation of Nrf2. } \\
\text { Elevated expression levels of HO-1. }\end{array}$ & [111] \\
\hline Geraniol & Isoproterenol-induced cardiotoxicity & $\begin{array}{c}\text { Increased GSH levels. } \\
\text { Elevated GPx, CAT, and SOD activities. } \\
\text { Activated Nrf2. } \\
\text { Upregulation of HO-1 expression. }\end{array}$ & [125] \\
\hline Kaempferol & Alcohol-induced liver injury in mice & $\begin{array}{c}\text { Increased antioxidant enzymes (superoxide } \\
\text { dismutase and glutathione). } \\
\text { Decreased malondialdehyde. } \\
\text { Attenuating the activity and expression of } \\
\text { CYP2E1. }\end{array}$ & [121] \\
\hline (-)-linalool & $\begin{array}{l}\text { Oxygen-glucose-deprivation-induced } \\
\text { neuronal injury }\end{array}$ & Significantly increased SOD. & [115] \\
\hline Linalool & $\begin{array}{l}\text { Amyloid-beta-induced cognitive deficits and } \\
\text { damages in mice }\end{array}$ & $\begin{array}{l}\text { Elevated dismutase and glutathione peroxidase } \\
\text { activities. } \\
\text { Reduced the malondialdehyde content. } \\
\text { Reduced the AChE level. } \\
\text { Activated the Nrf2/HO-1 signaling. }\end{array}$ & [123] \\
\hline Thymol & $\begin{array}{c}\text { Lipopolysaccharide-induced acute lung injury } \\
\text { mice } \\
\text { Model }\end{array}$ & $\begin{array}{l}\text { Decreased malondialdehyde and MPO levels. } \\
\text { Increased superoxide dismutase activity. }\end{array}$ & [120] \\
\hline Thymol & $\begin{array}{l}\text { Type } 2 \text { diabetes in a streptozotocin-induced rat } \\
\text { model }\end{array}$ & $\begin{array}{l}\text { Significantly improved FRAP value. } \\
\text { Decreased the levels of AOPP value. } \\
\text { Significantly decreased MDA level. } \\
\text { Elevated erythrocyte GSH levels. } \\
\text { Elevated \% DPPH. }\end{array}$ & [109] \\
\hline Thymol & LPS-induced acute lung injury in mice & $\begin{array}{l}\text { Significantly reduced the MPO activity. } \\
\text { Significantly reduced MDA content. }\end{array}$ & [124] \\
\hline
\end{tabular}

Shata and Eldebaky [118] evaluated the antioxidant activity of camphor oil against atrazine-induced oxidative stress in vivo. They found that camphor treatment at a concentration of $30 \mathrm{mg} / \mathrm{kg}$ showed antioxidant properties by the reduction in MDA levels and a significantly elevated activity of SOD. Rajan et al. [116] induced liver damage by $\mathrm{N}$-nitrosodiethylamine in experimental rats and measured lipid peroxidation and the antioxidant status. The authors noted that this monoterpene attenuates oxidative damage by increasing host enzymatic antioxidants (superoxide dismutase, catalase) and nonenzymic antioxidants (GPx, GR, GSH, G6PD, Vit. A, Vit. C, and Vit. E). This result was validated recently by Baranauskaite et al. [97], who reported that the daily administration of $0.0405 \mathrm{mg} / \mathrm{kg}$ of camphor protects the brain and liver against oxidative stress in rats via activation of the antioxidant defense system. On the other hand, the study of Mishra et al. [114] showed that treatment with citral at a concentration of $45 \mathrm{mg} / \mathrm{kg}$ to streptozotocin/high-fat-diet-induced diabetic dyslipidemic rats ameliorated the activity of SOD, catalase, GPx, and GR, and also increased GSH content in all tissues. It reduced lipid peroxidation and protein carbonyl content. Recently, Bagheri and collaborators investigated the antioxidant effects of D-limonene in alloxan-induced diabetic rats. They revealed that limonene treatment at a dose of $100 \mathrm{mg} / \mathrm{dL}$ significantly decreased serum MDA, MPO, and NO, while increasing GSH. This compound was also found to elevate GPx, CAT, and SOD levels in mRNA [110]. 
Geraniol is another terpenoids compound that showed antioxidant activity in vivo. In a study by Younis et al. [125], geraniol revealed a hepatoprotective effect in liver ischemia reperfusion injury induced by oxidative stress. This effect was associated with various molecular mechanisms, such as increasing the TAC and GSH levels, decreasing MDA levels, activation of $\mathrm{Nrf} 2$, as well as the upregulation of $\mathrm{HO}-1$ expression. In the same years, El-Emam et al. [111] confirmed this result. The authors reported that oral administration of geraniol 100 and $200 \mathrm{mg} / \mathrm{kg}$ exhibited a protective effect against isoproterenol-induced cardiotoxicity by decreasing Keap1 expression and increasing nuclear accumulation of Nrf2.

Kaempferol was tested against alcoholic liver injury in mice. It attenuated the activity and expression of CYP2E1 and reduced oxidative stress, as well as lipid peroxidation, and elevated the antioxidative system [121]. Moreover, the oral administration of linalool at a dose of $100 \mathrm{mg} / \mathrm{kg}$ reduced the AChE level, which has a close relationship with oxidative stress, and increased SOD and GPX, as well as activated Nrf2/HO-1 signaling [123].

Agarwal et al. [109] investigated the protective activity of thymol against $\beta$-cell damage induced by streptozotocin. This effect was concluded by assessing plasma MDA content, advanced oxidation protein products (AOPP), and sialic acid (SA). Markers of antioxidants, such as FRAP and GSH, were also measured. The results of the study demonstrated that giving thymol with a dose of $40 \mathrm{mg} / \mathrm{kg}$ reduced the MDA level, sialic acid and AOPP levels, and also elevated \% DPPH, FRAP content, and erythrocyte GSH levels.

\subsection{Clinical Evidence}

Clinical evidence of the natural antioxidant compound is a very crucial step for the development of a new antioxidant drug. Indeed, several studies have investigated this effect in patients or healthy individuals, and the results are presented in Table 4, which reports the compound names, the human subjects, and major results [127-135]. Agarwal et al. [127] examined the effect of catechin at a concentration of $500 \mu \mathrm{g}$ on biomarkers of oxidative stress in patients diagnosed with AFB-positive cases of pulmonary tuberculosis. Accordingly, catechin significantly decreased lipid peroxidation and NO production levels. It also decreased catalase, GPx, and SH levels, while increasing SOD and GSH levels.

Furthermore, De Groote and collaborators [131] demonstrated that catechin and resveratrol showed a protective effect against oxidative stress in obese subjects by numerous mechanisms, including the increase in the activity of GPX, SOD, TAP, and GSSG, a decrease in some oxidative damages, and modulation of the expression of genes involved in redox and cellular stress response pathways. In another study performed in 2014 on healthy postmenopausal women, acute ingestion of catechin had no substantial effect on the levels of postprandial oxidative stress markers, but increased postprandial TRX concentrations, which has a vital role in cellular function and protection by limiting oxidative stress directly via its antioxidant capacity [135]. Regarding quercetin, a study by Quindry et al. [134] investigated the antioxidant activity of quercetin supplementation against blood oxidative stress in athletes during ultramarathon competition. The authors showed that quercetin supplementation increased antioxidant capacity and plasma urate levels, while Troloxequivalent antioxidant capacity remained unaffected, as well as plasma F2-isoprostane values and plasma protein carbonyls (biomarkers of plasma oxidative damage) in athletes. In another work, Boots et al. [129] revealed that quercetin supplementation improved the antioxidant system by improving TAC and decreasing MDA concentration. This effect was confirmed by Duranti et al. [132], who demonstrated that this flavonoid decreased erythrocytes lipid peroxidation levels and improved redox status in healthy young after a strenuous eccentric exercise. Bumrungpert et al. [130] assessed the antioxidant activity of ferulic acid (1000 mg daily) in patients with hyperlipidemia by determination of biomarkers of oxidative stress and reported that ferulic acid supplementation improved oxidative stress by decreasing the MDA content (24.5\%). In another work, Ferk et al. [133] investigated the preventive activity of gallic acid $(15 \mathrm{mg} / \mathrm{p} / \mathrm{d})$ against oxidative stress in diabetic patients. Accordingly, gallic acid consumption did not affect MDA concentration, which is formed as a consequence of lipid peroxidation, as well as FRAP, which reflects the overall redox status, 
while protecting the genetic material against oxidative damage in the diabetic patients. In a clinical study by Alavinezhad et al. [128], asthmatic patients received carvacrol at a concentration of $1.2 \mathrm{mg} / \mathrm{kg} /$ day and reported a decrease in the plasma level of $\mathrm{NO}^{2-}$.

Table 4. Clinical evidence of antioxidant activity of natural compounds.

\begin{tabular}{|c|c|c|c|}
\hline Molecules & Human Subjects & Effects & Refs. \\
\hline Catechins & $\begin{array}{l}\text { Patients of AFB-positive pulmonary } \\
\text { tuberculosis. }\end{array}$ & $\begin{array}{l}\text { Decreased MDA concentration. } \\
\text { Decreased the level of NO production. } \\
\text { Significantly increased SOD. } \\
\text { Significantly decreased catalase and GPx level. } \\
\text { Significantly increased GSH. } \\
\text { Significant decrease in SH level. }\end{array}$ & [127] \\
\hline Catechin & Adult obese subjects & $\begin{array}{c}\text { Increased the gene expression, and also SOD and } \\
\text { GPX activity. } \\
\text { Reduced the levels of GSH. } \\
\text { Increased TAP and GSSG. } \\
\text { Decreased lipid peroxides. } \\
\text { Altered the expression of genes involved in } \\
\text { redox. }\end{array}$ & [131] \\
\hline Catechins & Healthy postmenopausal women & $\begin{array}{c}\text { No impact on serum d-ROM concentrations and } \\
\text { plasma } \mathrm{H}_{2} \mathrm{O}_{2} \\
\text { Elevated postprandial plasma TRX } \\
\text { concentrations. }\end{array}$ & [135] \\
\hline Quercetin & Athletes & $\begin{array}{c}\text { Significantly increased plasma FRAP. } \\
\text { Unaffected TEAC Plasma F2-isoprostane values } \\
\text { and protein carbonyls. }\end{array}$ & [134] \\
\hline Quercetin & $\begin{array}{l}\text { Non-smoking patients with symptomatic } \\
\text { sarcoidosis }\end{array}$ & $\begin{array}{l}\text { Increased total plasma antioxidant capacity. } \\
\text { Decreased MDA concentration. }\end{array}$ & [129] \\
\hline Quercetin & Healthy young & $\begin{array}{c}\text { Decrease in GSSG levels. } \\
\text { Improved GSH/GSSG ratio. } \\
\text { Significantly decreased TBARs levels. } \\
\text { No effect in erythrocytes CAT, GPx, SOD } \\
\text { activities, and SOD/GPx ratio. }\end{array}$ & [132] \\
\hline Ferulic acid & Subjects with hyperlipidemia & Decreased the oxidative stress biomarker, MDA. & [130] \\
\hline Gallic acid & Type 2 diabetes patients & No impact on plasma MDA and FRAP. & [133] \\
\hline Carvacrol & Asthmatic patients & Significantly decreased plasma level of $\mathrm{NO}^{2}-$. & [128] \\
\hline Resveratrol & Adult obese subjects & $\begin{array}{c}\text { Increased the gene expression, and also SOD and } \\
\text { GPX activity. } \\
\text { Reduced the levels of GSH and GSSG. } \\
\text { Increased TAP. } \\
\text { Decreased lipid peroxides. } \\
\text { Altered the expression of genes involved in } \\
\text { redox. }\end{array}$ & [131] \\
\hline
\end{tabular}

\section{Conclusions}

The use of natural antioxidants specifically targeting ROS generation will allow cellular oxidative stress to be avoided, and, consequently, minimize the epigenetic instability, which induces the first events of tumor transformation. Indeed, we have reported that natural antioxidant molecules have proven their effectiveness in vivo, as well as clinically, in the inhibition of oxidative stress (the effectors of stress and its generation). This demonstrates that these substances could build major molecular building blocks in the screening of antioxidant substances used in the prevention of human cancers. However, the molecular action of these substances on the generation of free radicals remains to be determined in future investigations. In addition, the action of these molecules should 
also be investigated in epigenetic modifiers to prevent epigenetic instability and tumor transformation. The clinical applications of these molecules as antioxidant drugs against oxidative-stress-related diseases, such as cancer, need further investigation. Indeed, toxicological studies are needed to validate the safety of these bioactive compounds. In addition, pharmacokinetic investigations should also be carried out to determine the distribution, metabolism, and elimination of these drugs. On the other hand, in our opinion, these substances should be also tested as epidrugs (in vivo and clinically) on different mediators of epigenetic modifications induced by oxidative stress. In this way, drugs that target oxidative-stress-inducing cancer via epigenetic-instability- and epigenetic-dysregulationinduced cell transformation could be screened and used in pharmaceutical applications to prevent and treat human cancers.

Author Contributions: A.B. (Abdelhakim Bouyahya), N.E.M., L.O., A.E.A., A.B. (Abdelaali Balahbib), M.T., and N.E.O. conceived the review idea and focus, and drafted the article. A.R., N.M., E.K., M.D., and M.A.S. were involved in the reference collection, and writing the article. All authors have read and agreed to the published version of the manuscript.

Funding: This paper was supported by the KU Research Professor Program of Konkuk University, Seoul, South Korea.

Conflicts of Interest: The authors declare no conflict of interest.

\section{References}

1. Martinez-Cayuela, M. Oxygen free radicals and human disease. Biochimie 1995, 77, 147-161. [CrossRef]

2. Szumiel, I. Ionizing radiation-induced oxidative stress, epigenetic changes and genomic instability: The pivotal role of mitochondria. Int. J. Radiat. Biol. 2015, 91, 1-12. [CrossRef] [PubMed]

3. Parohan, M.; Sadeghi, A.; Khatibi, S.R.; Nasiri, M.; Milajerdi, A.; Khodadost, M.; Sadeghi, O. Dietary Total antioxidant capacity and risk of cancer: A systematic review and meta-analysis on observational studies. Crit. Rev. Oncol. Hematol. 2019, 138, 70-86. [CrossRef] [PubMed]

4. Pizzino, G.; Irrera, N.; Cucinotta, M.; Pallio, G.; Mannino, F.; Arcoraci, V.; Squadrito, F.; Altavilla, D.; Bitto, A. Oxidative stress: Harms and benefits for human health. Oxid. Med. Cell. Longev. 2017, 2017, 8416763. [CrossRef]

5. De Jager, T.L.; Cockrell, A.E.; Du Plessis, S.S. Ultraviolet light induced generation of reactive oxygen species. In Ultraviolet Light in Human Health, Diseases and Environment. Advances in Experimental Medicine and Biology; Springer: Cham, Switzerland, 2017; Volume 996, pp. 15-23.

6. Kohen, R.; Nyska, A. Invited Review: Oxidation of biological systems: Oxidative stress phenomena, antioxidants, redox reactions, and methods for their quantification. Toxicol. Pathol. 2002, 30, 620-650. [CrossRef]

7. Magnani, F.; Mattevi, A. Structure and mechanisms of ROS generation by NADPH oxidases. Curr. Opin. Struct. Biol. 2019, 59, 91-97. [CrossRef]

8. Zhao, R.-Z.; Jiang, S.; Zhang, L.; Yu, Z.-B. Mitochondrial electron transport chain, ROS generation and uncoupling. Int. J. Mol. Med. 2019, 44, 3-15. [CrossRef]

9. Cho, K.-J.; Seo, J.-M.; Kim, J.-H. Bioactive lipoxygenase metabolites stimulation of NADPH oxidases and reactive oxygen species. Mol. Cells 2011, 32, 1-5. [CrossRef]

10. Battelli, M.G.; Polito, L.; Bortolotti, M.; Bolognesi, A. Xanthine Oxidoreductase-derived reactive species: Physiological and pathological effects. Oxid. Med. Cell. Longev. 2016, 2016, 3527579. [CrossRef]

11. Veith, A.; Moorthy, B. Role of Cytochrome P450s in the generation and metabolism of reactive oxygen species. Curr. Opin. Toxicol. 2018, 7, 44-51. [CrossRef]

12. Ali, E.M.; Soha, H.M.; Mohamed, T.M. Nitric oxide synthase and oxidative stress: Regulation of nitric oxide synthase. In Oxidative Stress: Molecular Mechanisms and Biological Effects; InTech: Rijeka, Croatia, 2012; pp. 61-72.

13. Schröder, K. NADPH Oxidases: Current aspects and tools. Redox Biol. 2020, 34, 101512. [CrossRef]

14. Wang, Y.; Branicky, R.; Noë, A.; Hekimi, S. Superoxide dismutases: Dual roles in controlling ROS damage and regulating ROS signaling. J. Cell Biol. 2018, 217, 1915-1928. [CrossRef]

15. Stuehr, D.J. Enzymes of the L-arginine to nitric oxide pathway. J. Nutr. 2004, 134, 2748S-2751S. [CrossRef]

16. Aratani, Y. Myeloperoxidase: Its Role for host defense, inflammation, and neutrophil function. Arch. Biochem. Biophys. 2018, 640, 47-52. [CrossRef]

17. Kanti Das, T.; Wati, M.R.; Fatima-Shad, K. Oxidative stress gated by Fenton and Haber Weiss reactions and its association with Alzheimer's Disease. Arch. Neurosci. 2015, 2, e60038. [CrossRef]

18. Sies, H. Strategies of antioxidant defense. In EJB Reviews; Springer: Berlin/Heidelber, Germany, 1993; pp. 101-107. [CrossRef]

19. Gutteridge, J.M. Lipid peroxidation initiated by superoxide-dependent hydroxyl radicals using complexed iron and hydrogen peroxide. FEBS Lett. 1984, 172, 245-249. [CrossRef] 
20. Redza-Dutordoir, M.; Averill-Bates, D.A. Activation of apoptosis signalling pathways by reactive oxygen species. Biochim. Biophys. Acta BBA Mol. Cell Res. 2016, 1863, 2977-2992. [CrossRef]

21. Wang, L.; Kuang, Z.; Zhang, D.; Gao, Y.; Ying, M.; Wang, T. Reactive oxygen species in immune cells: A new antitumor target. Biomed. Pharmacother. 2021, 133, 110978. [CrossRef]

22. Ji, A.-R.; Ku, S.-Y.; Cho, M.S.; Kim, Y.Y.; Kim, Y.J.; Oh, S.K.; Kim, S.H.; Moon, S.Y.; Choi, Y.M. Reactive oxygen species enhance differentiation of human embryonic stem cells into mesendodermal lineage. Exp. Mol. Med. 2010, 42, 175-186. [CrossRef]

23. Zhang, J.; Wang, X.; Vikash, V.; Ye, Q.; Wu, D.; Liu, Y.; Dong, W. ROS and ROS-mediated cellular signaling. Oxid. Med. Cell. Longev. 2016, 2016, 4350965. [CrossRef]

24. Ahmad, G.; Almasry, M.; Dhillon, A.S.; Abuayyash, M.M.; Kothandaraman, N.; Cakar, Z. Overview and sources of reactive oxygen species (ROS) in the reproductive system. In Oxidative Stress in Human Reproduction; Springer: Cham, Schwitzerland, 2017; pp. 1-16.

25. Simon, H.-U.; Haj-Yehia, A.; Levi-Schaffer, F. Role of reactive oxygen species (ROS) in apoptosis induction. Apoptosis 2000, 5, 415-418. [CrossRef]

26. Chaudière, J.; Ferrari-Iliou, R. Intracellular antioxidants: From chemical to biochemical mechanisms. Food Chem. Toxicol. 1999, 37, 949-962. [CrossRef]

27. McCord, J.M.; Fridovich, I. Superoxide dismutase: An enzymic function for erythrocuprein (hemocuprein). J. Biol. Chem. 1969, 244, 6049-6055. [CrossRef]

28. Nandi, A.; Yan, L.-J.; Jana, C.K.; Das, N. Role of catalase in oxidative stress-and age-associated degenerative diseases. Oxid. Med. Cell. Longev. 2019, 2019, 9613090. [CrossRef]

29. Sarıkaya, E.; Doğan, S. Glutathione Peroxidase in health and diseases. Glutathione System and Oxidative Stress in Health and Disease; Intech: Rijeka, Croatia, 2020.

30. Carlberg, I.; Mannervik, B. Glutathione reductase. Methods Enzymol. 1985, 113, 484-490.

31. Freinbichler, W.; Colivicchi, M.A.; Stefanini, C.; Bianchi, L.; Ballini, C.; Misini, B.; Weinberger, P.; Linert, W.; Varešlija, D.; Tipton, K.F. Highly reactive oxygen species: Detection, formation, and possible functions. Cell. Mol. Life Sci. 2011, 68, 2067-2079. [CrossRef]

32. Klaunig, J.E.; Wang, Z. Oxidative stress in carcinogenesis. Curr. Opin. Toxicol. 2018, 7, 116-121. [CrossRef]

33. Nakashima, I.; Kawamoto, Y.; Takeda, K.; Kato, M. Control of genetically prescribed protein tyrosine kinase activities by environment-linked redox reactions. Enzyme Res. 2011, 2011, 896567. [CrossRef]

34. Son, Y.; Cheong, Y.-K.; Kim, N.-H.; Chung, H.-T.; Kang, D.G.; Pae, H.-O. Mitogen-activated protein kinases and reactive oxygen species: How can ROS activate MAPK pathways? J. Signal Transduct. 2011, 2011, 792639. [CrossRef]

35. Cheng, C.W.; Kuo, C.Y.; Fan, C.C.; Fang, W.C.; Jiang, S.S.; Lo, Y.K.; Wang, T.Y.; Kao, M.C.; Lee, A.Y. Overexpression of Lon contributes to survival and aggressive phenotype of cancer cells through mitochondrial complex I-mediated generation of reactive oxygen species. Cell Death Dis. 2013, 4, e681. [CrossRef]

36. Shih, V.F.-S.; Tsui, R.; Caldwell, A.; Hoffmann, A. A Single NFkB System for both canonical and non-canonical signaling. Cell Res. 2011, 21, 86-102. [CrossRef] [PubMed]

37. Morgan, M.J.; Liu, Z. Crosstalk of reactive oxygen species and NF-KB signaling. Cell Res. 2011, 21, 103-115. [CrossRef] [PubMed]

38. Takada, Y.; Mukhopadhyay, A.; Kundu, G.C.; Mahabeleshwar, G.H.; Singh, S.; Aggarwal, B.B. Hydrogen peroxide activates NF-KB through tyrosine phosphorylation of IKB $\alpha$ and serine phosphorylation of P65: Evidence for the involvement of IKB $\alpha$ kinase and Syk protein-tyrosine kinase. J. Biol. Chem. 2003, 278, 24233-24241. [CrossRef] [PubMed]

39. Yang, J.; Nie, J.; Ma, X.; Wei, Y.; Peng, Y.; Wei, X. Targeting PI3K in cancer: Mechanisms and advances in clinical trials. Mol. Cancer 2019, 18, 1-28. [CrossRef]

40. Leslie, N.R.; Bennett, D.; Lindsay, Y.E.; Stewart, H.; Gray, A.; Downes, C.P. Redox regulation of PI 3-kinase signalling via inactivation of PTEN. EMBO J. 2003, 22, 5501-5510. [CrossRef]

41. Kitagishi, Y.; Matsuda, S. Redox regulation of tumor suppressor PTEN in cancer and aging. Int. J. Mol. Med. 2013, 31, 511-515. [CrossRef]

42. Lee, S.-R.; Yang, K.-S.; Kwon, J.; Lee, C.; Jeong, W.; Rhee, S.G. Reversible inactivation of the tumor suppressor $\mathrm{PTEN}$ by $\mathrm{H}_{2} \mathrm{O}_{2}$. J. Biol. Chem. 2002, 277, 20336-20342. [CrossRef]

43. Franke, T.F.; Wang, X.; McCullough, K.D.; Holbrook, N.J. Epidermal growth factor receptor-dependent akt activation by oxidative stress enhances cell survival. J. Biol. Chem. 2000, 275, 14624-14631.

44. Galanis, A.; Pappa, A.; Giannakakis, A.; Lanitis, E.; Dangaj, D.; Sandaltzopoulos, R. Reactive oxygen species and HIF-1 signalling in cancer. Cancer Lett. 2008, 266, 12-20. [CrossRef]

45. Liu, L.-Z.; Hu, X.-W.; Xia, C.; He, J.; Zhou, Q.; Shi, X.; Fang, J.; Jiang, B.-H. Reactive oxygen species regulate epidermal growth factor-induced vascular endothelial growth factor and hypoxia-inducible factor- $1 \alpha$ expression through activation of AKT and P70S6K1 in human ovarian cancer cells. Free Radic. Biol. Med. 2006, 41, 1521-1533. [CrossRef]

46. Lutz, W.K. Endogenous genotoxic agents and processes as a basis of spontaneous carcinogenesis. Mutat. Res. Genet. Toxicol. 1990, 238, 287-295. [CrossRef]

47. Jena, N.R. DNA Damage by reactive species: Mechanisms, Mutation and Repair. J. Biosci. 2012, 37, 503-517. [CrossRef]

48. Van Elsland, D.; Neefjes, J. Bacterial infections and cancer. EMBO Rep. 2018, 19, e46632. [CrossRef]

49. Sharma, S.; Kelly, T.K.; Jones, P.A. Epigenetics in cancer. Carcinogenesis 2010, 31, 27-36. [CrossRef] 
50. Donkena, K.V.; Young, C.Y.; Tindall, D.J. Oxidative stress and DNA methylation in prostate cancer. Obstet. Gynecol. Int. 2010, 2010, 302051. [CrossRef]

51. Bird, A. DNA Methylation patterns and epigenetic memory. Genes Dev. 2002, 16, 6-21. [CrossRef]

52. Nan, X.; Ng, H.-H.; Johnson, C.A.; Laherty, C.D.; Turner, B.M.; Eisenman, R.N.; Bird, A. Transcriptional repression by the methyl-CpG-binding protein MeCP2 involves a histone deacetylase complex. Nature 1998, 393, 386-389. [CrossRef]

53. Reyngold, M.; Chan, T.A. DNA methylation. In Molecular Oncology: Causes of Cancer and Targets for Treatment; Cambridge University Press: Cambridge, UK, 2018.

54. Ehrlich, M. DNA Hypomethylation in Cancer Cells. Epigenomics 2009, 1, 239-259. [CrossRef]

55. Valinluck, V.; Tsai, H.-H.; Rogstad, D.K.; Burdzy, A.; Bird, A.; Sowers, L.C. Oxidative Damage to methyl-CpG Sequences inhibits the binding of the methyl-CpG binding domain (MBD) of methyl-CpG binding protein 2 (MeCP2). Nucleic Acids Res. 2004, 32, 4100-4108. [CrossRef]

56. Grollman, A.P.; Moriya, M. Mutagenesis by 8-Oxoguanine: An Enemy Within. Trends Genet. 1993, 9, 246-249. [CrossRef]

57. Gening, L.V.; Volodin, A.A.; Kazachenko, K.Y.; Makarova, I.V.; Tarantul, V.Z. Estimation of the Mutagenic Potential of 8-Oxog in Nuclear Extracts of Mouse Cells Using the "Framed Mirror" Method. Methods Protoc. 2020, 3, 3. [CrossRef]

58. Franco, R.; Schoneveld, O.; Georgakilas, A.G.; Panayiotidis, M.I. Oxidative stress, DNA methylation and carcinogenesis. Cancer Lett. 2008, 266, 6-11. [CrossRef]

59. Lim, S.-O.; Gu, J.-M.; Kim, M.S.; Kim, H.-S.; Park, Y.N.; Park, C.K.; Cho, J.W.; Park, Y.M.; Jung, G. Epigenetic changes induced by reactive oxygen species in hepatocellular carcinoma: Methylation of the E-cadherin promoter. Gastroenterology 2008, 135, 2128-2140. [CrossRef]

60. Zhang, R.; Kang, K.A.; Kim, K.C.; Na, S.-Y.; Chang, W.Y.; Kim, G.Y.; Kim, H.S.; Hyun, J.W. Oxidative stress causes epigenetic alteration of CDX1 expression in colorectal cancer cells. Gene 2013, 524, 214-219. [CrossRef]

61. Romanenko, A.; Morell-Quadreny, L.; Lopez-Guerrero, J.A.; Pellin, A.; Nepomnyaschy, V.; Vozianov, A.; Llombart-Bosch, A. P16INK4A and P15INK4B gene alteration associated with oxidative stress in renal cell carcinomas after the chernobyl accident (Pilot Study). Diagn. Mol. Pathol. 2002, 11, 163-169. [CrossRef]

62. Castelli, G.; Pelosi, E.; Testa, U. Targeting histone methyltransferase and demethylase in acute myeloid leukemia therapy. OncoTargets Ther. 2018, 11, 131. [CrossRef]

63. Kouzarides, T. Chromatin Modifications and Their Function. Cell 2007, 128, 693-705. [CrossRef]

64. Luan, Y.; Ngo, L.; Han, Z.; Wang, X.; Qu, M.; Zheng, Y.G. Histone acetyltransferases: Enzymes, assays, and inhibitors. In Epigenetic Technological Applications; Elsevier: Amsterdam, The Netherlands, 2015; pp. 291-317.

65. O'Hagan, H.M.; Wang, W.; Sen, S.; Shields, C.D.; Lee, S.S.; Zhang, Y.W.; Clements, E.G.; Cai, Y.; Van Neste, L.; Easwaran, H. Oxidative damage targets complexes containing DNA methyltransferases, SIRT1, and polycomb members to promoter CpG Islands. Cancer Cell 2011, 20, 606-619. [CrossRef]

66. Place, R.F.; Li, L.-C.; Pookot, D.; Noonan, E.J.; Dahiya, R. MicroRNA-373 induces expression of genes with complementary promoter sequences. Proc. Natl. Acad. Sci. USA 2008, 105, 1608-1613. [CrossRef]

67. Piletič, K.; Kunej, T. MicroRNA epigenetic signatures in human disease. Arch. Toxicol. 2016, 90, 2405-2419. [CrossRef]

68. Calin, G.A.; Sevignani, C.; Dumitru, C.D.; Hyslop, T.; Noch, E.; Yendamuri, S.; Shimizu, M.; Rattan, S.; Bullrich, F.; Negrini, M. Human MicroRNA genes are frequently located at fragile sites and genomic regions involved in cancers. Proc. Natl. Acad. Sci. USA 2004, 101, 2999-3004. [CrossRef] [PubMed]

69. Humphries, B.; Wang, Z.; Yang, C. MicroRNA Regulation of Epigenetic Modifiers in Breast Cancer. Cancers 2019, $11,897$. [CrossRef] [PubMed]

70. He, J.; Jiang, B.-H. Interplay between reactive oxygen species and MicroRNAs in cancer. Curr. Pharmacol. Rep. 2016, 2, 82-90. [CrossRef] [PubMed]

71. He, J.; Xu, Q.; Jing, Y.; Agani, F.; Qian, X.; Carpenter, R.; Li, Q.; Wang, X.-R.; Peiper, S.S.; Lu, Z. Reactive oxygen species regulate ERBB2 and ERBB3 expression via MiR-199a/125b and DNA methylation. EMBO Rep. 2012, 13, 1116-1122. [CrossRef]

72. Tu, H.; Sun, H.; Lin, Y.; Ding, J.; Nan, K.; Li, Z.; Shen, Q.; Wei, Y. Oxidative stress upregulates PDCD4 expression in patients with gastric cancer via MiR-21. Curr. Pharm. Des. 2014, 20, 1917-1923. [CrossRef]

73. Degli Esposti, D.; Aushev, V.N.; Lee, E.; Cros, M.-P.; Zhu, J.; Herceg, Z.; Chen, J.; Hernandez-Vargas, H. MiR-500a-5p regulates oxidative stress response genes in breast cancer and predicts cancer survival. Sci. Rep. 2017, 7, 1-10. [CrossRef]

74. Wang, P.; Zhu, C.; Ma, M.; Chen, G.; Song, M.; Zeng, Z.; Lu, W.; Yang, J.; Wen, S.; Chiao, P.J. Micro-RNA-155 Is Induced by K-Ras oncogenic signal and promotes ROS stress in pancreatic cancer. Oncotarget 2015, 6, 21148. [CrossRef]

75. Demir, F.; Uzun, F.G.; Durak, D.; Kalender, Y. Subacute chlorpyrifos-induced oxidative stress in rat erythrocytes and the protective effects of catechin and quercetin. Pestic. Biochem. Physiol. 2011, 99, 77-81. [CrossRef]

76. Ganesan, D.; Holkar, A.; Albert, A.; Paul, E.; Mariakuttikan, J.; Sadasivam Selvam, G. Combination of ramipril and rutin alleviate alloxan induced diabetic nephropathy targeting multiple stress pathways in vivo. Biomed. Pharmacother. 2018, 108, 1338-1346. [CrossRef]

77. Gautam, R.; Singh, M.; Gautam, S.; Rawat, J.K.; Saraf, S.A.; Kaithwas, G. Rutin attenuates intestinal toxicity induced by methotrexate linked with anti-oxidative and anti-inflammatory effects. BMC Complement. Altern. Med. 2016, 16, 99. [CrossRef]

78. Han, J.-Y.; Ahn, S.-Y.; Kim, C.-S.; Yoo, S.-K.; Kim, S.-K.; Kim, H.-C.; Hong, J.T.; Oh, K.-W. Protection of apigenin against kainate-induced excitotoxicity by anti-oxidative effects. Biol. Pharm. Bull. 2012, 35, 1440-1446. [CrossRef] 
79. La Casa, C.; Villegas, I.; Alarcón de la Lastra, C.; Motilva, V.; Martín Calero, M.J. Evidence for protective and antioxidant properties of rutin, a natural flavone, against ethanol induced gastric lesions. J. Ethnopharmacol. 2000, 71, 45-53. [CrossRef]

80. Liu, H.; Guo, X.; Chu, Y.; Lu, S. Heart protective effects and mechanism of quercetin preconditioning on anti-myocardial ischemia reperfusion (IR) injuries in rats. Gene 2014, 545, 149-155. [CrossRef]

81. Liu, H.-J.; Fan, Y.-L.; Liao, H.-H.; Liu, Y.; Chen, S.; Ma, Z.-G.; Zhang, N.; Yang, Z.; Deng, W.; Tang, Q.-Z. Apigenin alleviates STZ-induced diabetic cardiomyopathy. Mol. Cell. Biochem. 2017, 428, 9-21. [CrossRef]

82. Mao, X.-Y.; Yu, J.; Liu, Z.-Q.; Zhou, H.-H. Apigenin attenuates diabetes-associated cognitive decline in rats via suppressing oxidative stress and nitric oxide synthase pathway. Int. J. Clin. Exp. Med. 2015, 8, 15506-15513.

83. Pan, X.; Shao, Y.; Wang, F.; Cai, Z.; Liu, S.; Xi, J.; He, R.; Zhao, Y.; Zhuang, R. Protective effect of apigenin magnesium complex on $\mathrm{H}_{2} \mathrm{O}_{2}$-induced oxidative stress and inflammatory responses in rat hepatic stellate cells. Pharm. Biol. 2020, 58, 553-560. [CrossRef]

84. Rizvi, S.I.; Zaid, M.A.; Anis, R.; Mishra, N. Protective role of tea catechins against oxidation-induced damage of type 2 diabetic erythrocytes. Clin. Exp. Pharmacol. Physiol. 2005, 32, 70-75. [CrossRef]

85. Roslan, J.; Giribabu, N.; Karim, K.; Salleh, N. Quercetin ameliorates oxidative stress, inflammation and apoptosis in the heart of streptozotocin-nicotinamide-induced adult male diabetic rats. Biomed. Pharmacother. 2017, 86, 570-582. [CrossRef]

86. Samie, A.; Sedaghat, R.; Baluchnejadmojarad, T.; Roghani, M. Hesperetin, a citrus flavonoid, attenuates testicular damage in diabetic rats via inhibition of oxidative stress, inflammation, and apoptosis. Life Sci. 2018, 210, 132-139. [CrossRef]

87. Somade, O.; Akinloye, O.; Adeyeye, M.; Fabunmi, G.; Idowu, O.; Badmus, F.; Salaudeen, B. Quercetin, a natural phytochemical and antioxidant protects against Sodium azide-induced hepatic and splenic oxidative stress in rats. J. Investig. Biochem. 2015, 4, 69. [CrossRef]

88. Wan, J.; Kuang, G.; Zhang, L.; Jiang, R.; Chen, Y.; He, Z.; Ye, D. Hesperetin Attenuated acetaminophen-induced hepatotoxicity by inhibiting hepatocyte necrosis and apoptosis, oxidative stress and inflammatory response via upregulation of heme oxygenase-1 expression. Int. Immunopharmacol. 2020, 83, 106435. [CrossRef]

89. Yang, X.; Yang, J.; Hu, J.; Li, X.; Zhang, X.; Li, Z. Apigenin attenuates myocardial ischemia/reperfusion injury via the inactivation of P38 mitogen-activated protein kinase. Mol. Med. Rep. 2015, 12, 6873-6878. [CrossRef]

90. Yelumalai, S.; Giribabu, N.; Karim, K.; Omar, S.Z.; Salleh, N.B. In vivo administration of quercetin ameliorates sperm oxidative stress, inflammation, preserves sperm morphology and functions in streptozotocin-nicotinamide induced adult male diabetic rats. Arch. Med. Sci. 2019, 15, 240-249. [CrossRef]

91. Yue, S.; Xue, N.; Li, H.; Huang, B.; Chen, Z.; Wang, X. Hepatoprotective effect of apigenin against liver injury via the non-canonical NF-KB pathway in vivo and in vitro. Inflammation 2020, 43, 1634-1648. [CrossRef]

92. Chen, W.-M.; Shaw, L.-H.; Chang, P.-J.; Tung, S.-Y.; Chang, T.-S.; Shen, C.-H.; Hsieh, Y.-Y.; Wei, K.-L. Hepatoprotective effect of resveratrol against ethanol-induced oxidative stress through induction of superoxide dismutase in vivo and in vitro. Exp. Ther. Med. 2016, 11, 1231-1238. [CrossRef]

93. Wang, H.-L.; Gao, J.-P.; Han, Y.-L.; Xu, X.; Wu, R.; Gao, Y.; Cui, X.-H. Comparative studies of polydatin and resveratrol on mutual transformation and antioxidative effect in vivo. Phytomedicine 2015, 22, 553-559. [CrossRef]

94. Prakash, R. Protective effect of resveratrol and celecoxib on lipopolysaccharide induced oxidative stress. Ramakrishnan Prakash J. Pharm. Sci. Res. 2019, 11, 1.

95. Wang, X.; Meng, L.; Zhao, L.; Wang, Z.; Liu, H.; Liu, G.; Guan, G. Resveratrol ameliorates hyperglycemia-induced renal tubular oxidative stress damage via modulating the SIRT1/FOXO3a pathway. Diabetes Res. Clin. Pract. 2017, 126, 172-181. [CrossRef]

96. Zhang, Y.-Q.; Liu, Y.-J.; Mao, Y.-F.; Dong, W.-W.; Zhu, X.-Y.; Jiang, L. Resveratrol ameliorates lipopolysaccharide-induced epithelial mesenchymal transition and pulmonary fibrosis through suppression of oxidative stress and transforming growth factor-B1 signaling. Clin. Nutr. 2015, 34, 752-760. [CrossRef]

97. Baranauskaite, J.; Sadauskiene, I.; Liekis, A.; Kasauskas, A.; Lazauskas, R.; Zlabiene, U.; Masteikova, R.; Kopustinskiene, D.M.; Bernatoniene, J. Natural compounds rosmarinic acid and carvacrol counteract aluminium-induced oxidative stress. Molecules 2020, 25, 1807. [CrossRef]

98. Carrasco-Legleu, C.E. A single dose of caffeic acid phenethyl ester prevents initiation in a medium-term rat hepatocarcinogenesis model. World J. Gastroenterol. 2006, 12, 6779. [CrossRef] [PubMed]

99. Dianat, M.; Hamzavi, G.R.; Badavi, M.; Samarbafzadeh, A. Effects of losartan and vanillic acid co-administration on ischemiareperfusion-induced oxidative stress in isolated rat heart. Iran. Red Crescent Med. J. 2014, 16, e16664. [CrossRef] [PubMed]

100. Gerin, F.; Erman, H.; Erboga, M.; Sener, U.; Yilmaz, A.; Seyhan, H.; Gurel, A. The Effects of ferulic acid against oxidative stress and inflammation in formaldehyde-induced hepatotoxicity. Inflammation 2016, 39, 1377-1386. [CrossRef] [PubMed]

101. Govindaraj, J.; Sorimuthu Pillai, S. Rosmarinic acid modulates the antioxidant status and protects pancreatic tissues from glucolipotoxicity mediated oxidative stress in high-fat diet: Streptozotocin-induced diabetic rats. Mol. Cell. Biochem. 2015, 404, 143-159. [CrossRef]

102. Akdemir, F.N.E.; Gozeler, M.S.; Yildirim, S.; Askin, S.; Dortbudak, M.B.; Kiziltunc, A. The effect of ferulic acid against cisplatininduced ototoxicit. Med. Sci. Int. Med. J. 2018, 7, 528-531. [CrossRef]

103. Nabavi, S.F.; Habtemariam, S.; Di Lorenzo, A.; Sureda, A.; Khanjani, S.; Nabavi, S.M.; Daglia, M. Post-stroke depression modulation and in vivo antioxidant activity of gallic acid and its synthetic derivatives in a murine model system. Nutrients 2016, 8, 248. [CrossRef] 
104. Shen, Y.; Song, X.; Li, L.; Sun, J.; Jaiswal, Y.; Huang, J.; Liu, C.; Yang, W.; Williams, L.; Zhang, H.; et al. Protective effects of p-coumaric acid against oxidant and hyperlipidemia-an in vitro and in vivo evaluation. Biomed. Pharmacother. 2019, 111, 579-587. [CrossRef]

105. Sun, J.; Li, Y.; Ding, Y.; Wang, J.; Geng, J.; Yang, H.; Ren, J.; Tang, J.; Gao, J. Neuroprotective effects of gallic acid against hypoxia/reoxygenation-induced mitochondrial dysfunctions in vitro and cerebral ischemia/reperfusion injury in vivo. Brain Res. 2014, 1589, 126-139. [CrossRef]

106. Thingore, C.; Kshirsagar, V.; Juvekar, A. Amelioration of oxidative stress and neuroinflammation in lipopolysaccharide-induced memory impairment using rosmarinic acid in mice. Metab. Brain Dis. 2021, 36, 299-313. [CrossRef]

107. Tolba, M.F.; El-Serafi, A.T.; Omar, H.A. Caffeic acid phenethyl ester protects against glucocorticoid-induced osteoporosis in vivo: Impact on oxidative stress and RANKL/OPG signals. Toxicol. Appl. Pharmacol. 2017, 324, 26-35. [CrossRef]

108. Yuan, J.; Ge, K.; Mu, J.; Rong, J.; Zhang, L.; Wang, B.; Wan, J.; Xia, G. Ferulic acid attenuated acetaminophen-induced hepatotoxicity though down-regulating the cytochrome P 2E1 and inhibiting toll-like receptor 4 signaling-mediated inflammation in mice. Am. J. Transl. Res. 2016, 8, 4205-4214.

109. Agarwal, S.; Tripathi, R.; Mohammed, A.; Rizvi, S.I.; Mishra, N. Effects of thymol supplementation against type 2 diabetes in streptozotocin-induced rat model. Plant Arch. 2020, 20, 7.

110. Bagheri, S.; Sarabi, M.M.; Gholami, M.; Assadollahi, V.; Khorramabadi, R.M.; Moradi, F.H.; Ahmadvand, H. D-Limonene in diabetic rats. J. Ren. Inj. Prev. 2021, 10, 8.

111. El-Emam, S.Z.; Soubh, A.A.; Al-Mokaddem, A.K.; Abo El-Ella, D.M. Geraniol activates Nrf-2/HO-1 signaling pathway mediating protection against oxidative stress-induced apoptosis in hepatic ischemia-reperfusion injury. Naunyn. Schmiedebergs Arch. Pharmacol. 2020, 393, 1849-1858. [CrossRef]

112. Jamshidi, H.R.; Zeinabady, Z.; Zamani, E.; Shokrzadeh, M.; Shaki, F. Attenuation of diabetic nephropathy by carvacrol through anti-oxidative effects in alloxan-induced diabetic Rats. Res. J. Pharmacogn. 2018, 5, 57-64. [CrossRef]

113. Jiang, Z.-S.; Pu, Z.-C.; Hao, Z.-H. Carvacrol protects against spinal cord injury in rats via suppressing oxidative stress and the endothelial nitric oxide synthase pathway. Mol. Med. Rep. 2015, 12, 5349-5354. [CrossRef]

114. Mishra, C.; Khalid, M.; Fatima, N.; Singh, B.; Tripathi, D.; Waseem, M.; Mahdi, A.A. Effects of citral on oxidative stress and hepatic key enzymes of glucose metabolism in streptozotocin/high-fat-diet induced diabetic dyslipidemic Rats. Iran. J. Basic Med. Sci. 2018, 22, 49-57. [CrossRef]

115. Park, H.; Seol, G.H.; Ryu, S.; Choi, I.-Y. Neuroprotective effects of (-)-Linalool against oxygen-glucose deprivation-induced neuronal injury. Arch. Pharm. Res. 2016, 39, 555-564. [CrossRef]

116. Rajan, B.; Ravikumar, R.; Premkumar, T.; Devaki, T. Carvacrol attenuates N-nitrosodiethylamine induced liver injury in experimental Wistar rats. Food Sci. Hum. Wellness 2015, 4, 66-74. [CrossRef]

117. Samarghandian, S.; Farkhondeh, T.; Samini, F.; Borji, A. Protective effects of carvacrol against oxidative stress induced by chronic stress in rat's brain, liver, and kidney. Biochem. Res. Int. 2016, 2016, e2645237. [CrossRef]

118. Shata, F.Y.H.; Eldebaky, H.A.A. Effects of camphor on hepatic enzymes, steroids and antioxidant capacity of male rats intoxicated with atrazine. Middle-East J. Sci. Res. 2014, 22, 9.

119. Shoorei, H.; Khaki, A.; Khaki, A.A.; Hemmati, A.A.; Moghimian, M.; Shokoohi, M. The ameliorative effect of carvacrol on oxidative stress and germ cell apoptosis in testicular tissue of adult diabetic rats. Biomed. Pharmacother. 2019, 111, 568-578. [CrossRef]

120. Wan, L.; Meng, D.; Wang, H.; Wan, S.; Jiang, S.; Huang, S.; Wei, L.; Yu, P. Preventive and therapeutic effects of thymol in a lipopolysaccharide-induced acute lung injury mice model. Inflammation 2018, 41, 183-192. [CrossRef]

121. Wang, M.; Sun, J.; Jiang, Z.; Xie, W.; Zhang, X. Hepatoprotective effect of kaempferol against alcoholic liver injury in mice. Am. J. Chin. Med. 2015, 43, 241-254. [CrossRef]

122. Wei, H.-K.; Xue, H.-X.; Zhou, Z.X.; Peng, J. A carvacrol-thymol blend decreased intestinal oxidative stress and influenced selected microbes without changing the messenger RNA levels of tight junction proteins in Jejunal mucosa of weaning piglets. Animal 2017, 11, 193-201. [CrossRef]

123. Xu, P.; Wang, K.; Lu, C.; Dong, L.; Gao, L.; Yan, M.; Aibai, S.; Yang, Y.; Liu, X. Protective effects of linalool against amyloid beta-induced cognitive deficits and damages in mice. Life Sci. 2017, 174, 21-27. [CrossRef]

124. Yao, L.; Hou, G.; Wang, L.; Zuo, X.; Liu, Z. Protective effects of thymol on lps-induced acute lung injury in mice. Microb. Pathog. 2018, 116, 8-12. [CrossRef] [PubMed]

125. Younis, N.S.; Abduldaium, M.S.; Mohamed, M.E. Protective effect of geraniol on oxidative, inflammatory and apoptotic alterations in isoproterenol-induced cardiotoxicity: Role of the Keap1/Nrf2/HO-1 and PI3K/Akt/MTOR pathways. Antioxidants 2020, 9, 977. [CrossRef]

126. Yu, W.; Liu, Q.; Zhu, S. Carvacrol protects against acute myocardial infarction of rats via anti-oxidative and anti-apoptotic pathways. Biol. Pharm. Bull. 2013, 36, 579-584. [CrossRef]

127. Agarwal, A.; Prasad, R.; Jain, A. Effect of green tea extract (catechins) in reducing oxidative stress seen in patients of pulmonary tuberculosis on DOTS Cat I regimen. Phytomedicine 2010, 17, 23-27. [CrossRef]

128. Alavinezhad, A.; Hedayati, M.; Boskabady, M.H. The effect of Zataria multiflora and carvacrol on wheezing, FEV1 and plasma levels of nitrite in asthmatic patients. Avicenna J. Phytomed. 2017, 7, 531-541. [PubMed] 
129. Boots, A.W.; Drent, M.; de Boer, V.C.J.; Bast, A.; Haenen, G.R.M.M. Quercetin reduces markers of oxidative stress and inflammation in sarcoidosis. Clin. Nutr. 2011, 30, 506-512. [CrossRef] [PubMed]

130. Bumrungpert, A.; Lilitchan, S.; Tuntipopipat, S.; Tirawanchai, N.; Komindr, S. Ferulic acid supplementation improves lipid profiles, oxidative stress, and inflammatory status in hyperlipidemic subjects: A randomized, double-blind, placebo-controlled clinical trial. Nutrients 2018, 10, 713. [CrossRef] [PubMed]

131. De Groote, D.; Van Belleghem, K.; Devière, J.; Van Brussel, W.; Mukaneza, A.; Amininejad, L. Effect of the Intake of resveratrol, resveratrol phosphate, and catechin-rich grape seed extract on markers of oxidative stress and gene expression in adult obese subjects. Ann. Nutr. Metab. 2012, 61, 15-24. [CrossRef]

132. Duranti, G.; Ceci, R.; Patrizio, F.; Sgrò, P.; Di Luigi, L.; Sabatini, S.; Felici, F.; Bazzucchi, I. Chronic consumption of quercetin reduces erythrocytes oxidative damage: Evaluation at resting and after eccentric exercise in humans. Nutr. Res. 2018, 50, 73-81. [CrossRef]

133. Ferk, F.; Kundi, M.; Brath, H.; Szekeres, T.; Al-Serori, H.; Mišík, M.; Saiko, P.; Marculescu, R.; Wagner, K.-H.; Knasmueller, S. Gallic Acid improves health-associated biochemical parameters and prevents oxidative damage of DNA in type 2 diabetes patients: Results of a placebo-controlled pilot study. Mol. Nutr. Food Res. 2018, 62, 1700482. [CrossRef]

134. Quindry, J.C.; McAnulty, S.R.; Hudson, M.B.; Hosick, P.; Dumke, C.; McAnulty, L.S.; Henson, D.; Morrow, J.D.; Nieman, D. Oral quercetin supplementation and blood oxidative capacity in response to ultramarathon competition. Int. J. Sport Nutr. Exerc. Metab. 2008, 18, 601-616. [CrossRef]

135. Takahashi, M.; Miyashita, M.; Suzuki, K.; Bae, S.-R.; Kim, H.-K.; Wakisaka, T.; Matsui, Y.; Takeshita, M.; Yasunaga, K. Acute ingestion of catechin-rich green tea improves postprandial glucose status and increases serum thioredoxin concentrations in postmenopausal women. Br. J. Nutr. 2014, 112, 1542-1550. [CrossRef] 